Krzysztof A. Kuczyński

Łódź

\title{
LITERACCY POLONOFILE
}

Austriacko-polskie powinowactwa kulturalne od dawna należą do niezwykle obszernego, $\mathrm{i}$ - poniekąd - historycznie niecodziennego zjawiska. Pamiętać bowiem należy, że - w przeciwieństwie do innych pól recepcyjnych, jak relacje polsko-rosyjskie czy polsko-niemieckie - nasz kraj nigdy nie miał wspólnej granicy państwowej z Republiką Austrii (czy wcześniej: Monarchią Austro-Węgierską), co - jak wiadomo - zazwyczaj ożywia obustronne relacje. Jest też swoistym fenomenem, że nawet w okresie politycznej podległości naszego kraju podczas zaborów, dzięki stosunkowo łagodnym formom zwierzchności (pamiętamy, że np. Kazimierz Badeni był premierem Austrii, a liczni polscy politycy piastowali stanowiska ministrów) ${ }^{1}$, mogła swobodnie rozwijać się austriacko-polska wymiana kulturalna, w tym literacka ${ }^{2}$.

Także po 1945 roku, w kontekście „zimnej wojny” w kontaktach z Republiką Federalną Niemiec, była Austria swoistym „okienkiem” na świat zachodni. Tam właśnie ukazało się wiele polskich utworów, a austriackie teatry sporo uwagi poświęciły naszym sztukom, wystawiając je w reżyserii cenionych ludzi sceny. Na taką sytuację polskiej kultury w Austrii pracowali przez lata dosyć liczni znawcy i entuzjaści naszego piśmiennictwa.

W najnowszych dziejach polsko-austriackich kontaktów kulturalnych i literackich odnotować można stosunkowo liczne postacie austriackich uczonych, pisarzy i tłumaczy, którzy swą działalnością przyczynili się

${ }^{1}$ Por.m.in.: W. Łazuga, "Rzady polskie” w Austrii. Gabinet Kazimierza hr. Badeniego 18951897, Poznań 1991; Austria-Polska. Z dziejów sąsiedztwa, pod red. W. Leitscha i M. Wawrykowej, Warszawa-Wiedeń 1989; W. Łazuga, Kalkulować... Polacy na szczytach c.k. Monarchii, Warszawa 2013.

${ }^{2}$ E. Hurnikowa, W kręgu wiedeńskiej moderny. Z zagadnień polsko-austriackich powinowactw literacko-kulturowych, Częstochowa 2000; taż, W Cekanii i gdzie indziej. Studia i szkice o literaturze i kulturze austriackiej i polskiej, Częstochowa 2011. 
do zacieśnienia kulturalnych powinowactw pomiędzy obydwoma państwami. Wymienić tutaj można z sylwetek okresu powojennego Franza Theodora Csokora ${ }^{3}$, Ottona Forst de Battaglię ${ }^{4}$, Bonifacego Miązka ${ }^{5}$, Ferdinanda Neureitera ${ }^{6}$, Günthera Wytrzensa7, Gerdę Leber-Hagenau czy Oskara Jana Tauschinskiego, nazywanego nie bez słuszności, jednym z najwybitniejszych ludzi polsko-austriackiego pogranicza kulturowego ${ }^{8}$.

Na taką pozycję zasłużył sobie wiedeński pisarz i tłumacz wieloletnią pracą nad upowszechnianiem naszej kultury nad Dunajem, zarówno w postaci utworów oryginalnych o tematach i motywach polskich, m.in. Wer ist diese Frau ?, Talmi, Die Variation, Sakrileg, Der Jiingling im Baumstamm, jak esejów i szkiców, np. o St. J. Lecu, T. Rittnerze lub polskiej literaturze młodzieżowej, czy dzięki translacjom z naszego piśmiennictwa, m.in. J. Andrzejewskiego, R. Brandstaettera, A. Kuśniewicza, M. Kuncewiczowej, J. Himilsbacha, St. J. Leca, T. Karpowicza, M. Białoszewskiego, W. Szymborskiej, Z. Herberta, S. Grochowiaka, E. Brylla, J. Przybosia, głównie z zakresu literatury dla młodego czytelnika, jak J. Tuwim, J. Kulmowa, J. Domagalik, M. Górska, K. Dębnicki czy A. Bahdaj’.

3 B. Brandys, Franz Theodor Csokor. Identität von Leben und Werk, Łódź 1988; Franz Theodor Csokor. Amicus amicorum, hrsg. von B. Brandys, Łódź 1994.

${ }^{4}$ Por. m.in.: K. Huszcza, Polska i Polacy w pracach Ottona Forst de Battaglii, Kraków 2002; Człowiek Śródeuropy. Otto Forst de Battaglia (1889-1965,) pod red. K. Huszczy, A. Juzwenki i M. Zybury, Wrocław 2011.

5 Por.m.in.: K. A Kuczyński, Ze wsi w daleki świat. O życiu i twórczości ks. prof. Bonifacego Miazka, Łódź 2007; Powrót do domu Księdzu Infułatowi prof. dr hab. Bonifacemu Miazkowi w 75. rocznice urodzin. Księga Jubileuszowa, pod red. H. Kołodziejczyka, K.A. Kuczyńskiego i P. Obrączki, Łódź 2010;

6 Por. Ferdinand Neureiter (red.), "Austria-Polska”, 1973, nr 2.

7 K.A. Kuczyński, Günther Wytrzens (1922-1991). Wiedeński slawista ze Ślaska, Zeszyty Naukowe PWSZ w Płocku, Neofilologia t. 1, 2001.

8 O. Budrewicz, Człowiek pogranicza, Perspektywy, 1983, nr 35, s. 12.

9 Por. m.in.: E. Rosner, Oskar Jan Tauschinski. Portret tłumacza, Literatura na świecie, 1972, nr 1; tenże, Polonofil z Wiednia, Poglądy, 1978, nr 10; tenże, Polnische Motive bei Oskar Tauschinski [w:] Österreichisch-polnische literarische Nachbarschaft, pod red. H. Orłowskiego, Poznań 1979; S. H. Kaszyński, Posłowie [w:] O. J. Tauschinski, Świętokradztwo, Gdańsk 1976; J. Koprowski, Przyjaciel polskiego stowa [w:] U nas i gdzie indziej, Katowice, 1975; R. Taborski, Z problematyki polsko-austriackiego pogranicza literackiego. Od Tadeusza Rittnera do Oskara Jana Tauschinskiego [w:] Wiktoria Wiedeńska i stosunki polsko-austriackie 1683-1983, pod red. W. Śladkowskiego i A.A. Witusika, Lublin 1983; tenże, Oskar Jan Tauschinski-laureat nagrody Polskiego Oddziału SEC [w:] tenże, Wśród wiedeńskich poloników, II wydanie, Kraków-Wrocław 1983; K. A. Kuczyński, Oskar Jan Tauschinski, tłumacz i popularyzator literatury polskiej w Austrii, Zeszyty Naukowe UŁ, seria I, nr 47, 1979; K. A. Kuczyński, E. Rosner, Oskar Jan Tauschinski i Helene Lahr. Przyczynek do polsko-austriackich stosunków literackich, Ruch Literacki, 1983, nr 5; K. A. Kuczyński, Austriacki przyjaciel polskiego słowa, Przekrój, 1987, 30.VIII; E. Rosner, Oskar Jan Tauschinski - przyjaciel Polaków [w:] tenże, Znad Wisty i Dunaju. Szkice o polsko-austriackich powiazaniach literackich, Cieszyn 1998. 
Genezy zainteresowań Polską i Polakami należy niewątpliwie szukać u Oskara Jana Tauschinskiego w jego rodowodzie, pochodził on bowiem - jak to trafnie zauważył Roman Taborski - „z tak charakterystycznej dla dawnej monarchii habsburskiej mieszanej polsko-austriackiej rodziny"10. Przodkowie Oskara Jana Tauschinskiego mieli silne związki z Morawami i Chorwacją. „Gniazdem rodzinnym Tauschinskiego są Szlapanice koło Brna, na Morawach. Stamtąd rozeszli się po świecie"11, i tak np. pradziadek Oskara, oficer cesarsko-królewskiej armii, ożenił się z Chorwatką zaś w Zagrzebiu urodził się jego dziadek Stefan, także oficer armii austriackiej. Brat dziadka Stefana, Hipolit, wszedł na karty historii jako współzałożyciel partii socjalistycznej w Austrii.

Dziadek Stefan ożenił się z - pochodzącą z Prus - lwowianką Emmą Doms, która jako posag otrzymała majątek ziemski (5 wsi galicyjskich) w powiecie bobreckim. Ich dzieci, dwaj synowie - Robert (ojciec Oskara) i Stefan - uczęszczali we Lwowie do polskiego gimnazjum, obaj mówili dobrze po polsku.

Robert Tauschinski urodził się w roku 1885 w Wiedniu, gdzie czasowo stacjonował ze swym pułkiem jego ojciec Stefan. Z czasem Stefan Tauschinski uzyskał wcześniejszą emeryturę i osiadł w dobrach żony w Galicji. Robert - jak wspomniano powyżej - ukończył polskie gimnazjum we Lwowie, a następnie rozpoczął studia prawnicze na Uniwersytecie Wiedeńskim, ukoronowane tytułem doktora praw; uzyskał też absolutorium jako agronom w wiedeńskiej Hochschule für Bodenkultur. W roku 1909 ożenił się z lwowianką Hildą Stromenger, pochodzącą z rodziny kolonistów niemieckich, osiadłej od kilku pokoleń we Lwowie i mówiąca po polsku. Hilda po ukończeniu gimnazjum pragnęła zostać skrzypaczka, była uczennicą znanego pedagoga Sevcika; jej brat, Karol Stromenger, był cenionym muzykologiem i krytykiem.

Hilda i Robert Tauschinscy mieli dwóch synów: Roberta, urodzonego w 1910 roku w Halle/Saale, gdzie ojciec kontynuował studia agronomiczne, oraz Oskara, urodzonego w Żabokrukach, w jednej z pięciu wsi galicyjskich, otrzymanych przed laty w posagu przez babkę Emmę.

$* \quad * \quad *$

10 R. Taborski, Oskar Jan Tauschinski-laureat..., s. 212.

11 O. Budrewicz, Człowiek pogranicza..., s. 12. 
Oskar Alfred Tauschinski (imię Jan dołączył pisarz do swego nazwiska dopiero w latach trzydziestych) urodził się 8 czerwca 1914 roku w Żabokrukach, we wschodniej Galicji. Jako siedmiotygodniowe niemowlę przyjechał z rodzicami do Wiednia, dokąd ojciec jako rotmistrz rezerwy pułku ułanów otrzymał powołanie mobilizacyjne.

W Wiedniu rodzina Tauschinskich przebywała do 1917 roku, po czym przez kilka lat mieszkała na zmianę w Żabokrukach i we Lwowie, posiadając od 1918 roku polskie obywatelstwo. W roku 1922 sprzedano posiadłości galicyjskie, a następnie Tauschinscy przenoszą się do Gdańska, gdzie ojciec - pracujący jeszcze we Lwowie jako prawnik w bankach - objął kierownictwo filii Powszechnego Banku Związkowego, założonego przez Wiener Bankverein.

Oskar Tauschinski w latach 1923-1933 uczęszcza początkowo do gimnazjum niemieckiego, następnie - wraz ze swym starszym bratem Robertem - kończy Gimnazjum Polskie Macierzy Szkolnej. Okres ten wspominał po wielu latach pisząc: „...z polskiego gimnazjum w Gdańsku pozostały mi (...) w żywej pamięci dwie wybitne osobistości wśród moich nauczycieli: Jadwiga Frankowska i Edwin Jędrkiewicz. Na ich umysłowych i ludzkich wartościach poznałem się już za młodu. Im zawdzięczam wiele impulsów i wiele wskazówek, które mi przez całe życie były potrzebne i ważne"12. Gdańskie lata to młodość Tauschinskiego, nic dziwnego, że echa tamtych lat odnajdujemy niejednokrotnie $w$ jego dalszych wypowiedziach: „Mieszkałem w Gdańsku od ósmego do osiemnastego roku życia. Chodziłem do niemieckiej szkoły w Oliwie, a w ostatnich latach do polskiego gimnazjum w Petershagen. Nie wiem, jak to się dziś nazywa... Było to jedyne polskie gimnazjum Macierzy Szkolnej i bez porównania lepsze od tych pruskich szkół. Lepszy system pedagogiczny i wielu dobrych nauczycieli... Miałem wielu przyjaciół niemieckich i polskich. Ale mój brat chodził tylko do polskiej szkoły. Polacy byli w mniejszości i dlatego ulegali, bo byli słabsi. Dla słabszych miałem zawsze więcej sympatii niż dla tych, którzy biją... Nie był ten Gdańsk ani niemiecki, ani polski, ale pełen wrogich instynktów. Mentalność takiego pogranicza była strasznie przykra..."13.

Rodzina Tauschinskich przenosi się w 1933 roku z Gdańska-Oliwy do Sopotu, a następnie do Gdyni, gdzie mieszka do 1939 roku. Oskar Tauschinski po zdaniu matury w 1933 roku wyjeżdża w marcu tegoż roku do Wiednia, gdzie studiuje w Hochschule für Welthandel, dyplom uzyskuje w roku 1936.

12 O. J. Tauschinski, (bez tytułu), Punkt, 1979, nr 8, s. 119.

${ }^{13}$ L. Niekrasz, Wiedeńczyk z gdańska przeszłościa, Wybrzeże, 1984, nr 12, s. 34. 
W Wiedniu poznaje tamtejsze środowisko literackie, wówczas to poczęła kształtować się jego osobowość intelektualna ${ }^{14}$. Szczególnie Alma Johanna Koenig, znana i ceniona pisarka, wywarła - według słów Tauschinskiego - wielki wpływ na jego rozwój: „Poznałem ją jesienią 1933 roku, straciłem w maju 1942, kiedy została wywieziona do obozu koncentracyjnego. To było dziewięć najważniejszych lat mojego życia. Z subiektywnego punktu widzenia moje życie nie zaczęło się 8 czerwca 1914 roku w Żabokrukach, lecz 24 października 1933 roku w Wiedniu..."15.

Oskar Jan Tauschinski przygotowuje pod kierunkiem prof. Dietricha rozprawę doktorską pt. Verkehrsgeographie Polens; wyjeżdżając latem 1938 roku z odwiedzinami do rodziców do Sopotu, brakuje mu do egzaminu doktorskiego 1 rygorozum, planuje uzupełnić to wkrótce po powrocie do Wiednia. Jednak w Polsce-jako obywatel polski-zostaje we wrześniu 1938 roku powołany do odbycia służby wojskowej w Grudziądzu, w szkole podchorążych. „Ten okres - wspomina pisarz - utwierdził mnie w wyborze Wiednia jako ojczyzny, zrazili mnie ci chłopcy z Grudziądza, potrząsający szabelką, dosyć tacy szowinistyczni"16.

Podczas wojny Oskar Jan Tauschinski walczy po stronie polskiej, w szeregach 65 Pułku Piechoty wziął udział w bitwie nad Bzurą.

Oskar Jan Tauschinski dostaje się do niewoli niemieckiej, rok czasu przebywa w stalagu VI A, następnie zostaje zwolniony „w charakterze cywilnego Polaka (Zivilpole) z nakazem pozostania i podjęcia pracy na terenie Rzeszy. Tauschinski natychmiast porozumiał się z mieszkającym w Wiedniu stryjem, który ściągnął go do siebie i pomógł w zdobyciu paszportu bezpaństwowca"17. W roku 1944 wskutek prezentowania antyfaszystowskiej postawy był Tauschinski więziony przez wiedeńskie gestapo, po wojnie Oskar Jan Tauschinski zostaje w Wiedniu, od 1947 roku jest obywatelem austriackim.

W latach 1941 -1947 Oskar Jan Tauschinski zatrudniony jest w firmie tekstylnej, po wojnie zajmuje się także ceramika, wypalając z gliny barokowe figurki; pierwsze spotkanie z literaturą to porządkowanie spuścizny pisarskiej po Almie Johannie Koenig, a także - wraz z Heleną Lahr - opracowywanie manuskryptów obcych autorów dla wydawnictw, np. dla oficyny Ullsteina.

14 O. J. Tauschinski, Erinnerung - eine "mysteriöse“ Macht, Podium, 1979, nr 4, (34), s. $12-17$.

${ }_{15}$ O. Budrewicz, Człowiek..., s. 12; por. także: E Rosner, Między erosem a caritas. Życie i twórczość Almy Johanny Koenig 1887-1942?, Katowice 1987.

16 Przegrana? Z Oskarem Janem Tauschinskim rozmawia T. Krzemień, Tu i Teraz, 1983, nr 32, s. 1.

17 O. Budrewicz, Człowiek..., s. 12. 
Od stycznia 1952 roku do czerwca 1979 pracuje Oskar Jan Tauschinski jako redaktor w Österreichischer Buchklub der Jugend, bierze czynny udział w życiu kulturalnym stolicy Austrii. Był vice-prezesem Związku Pisarzy Austriackich, członkiem zarządu Austriackiego PEN-Clubu, członkiem Towarzystwa Austriacko-Polskiego. Oskar Jan Tauschinski był fundatorem cenionej nagrody literackiej im. Almy Johanny Koenig, ojej celach i znaczeniu powiedział kiedyś następująco: „Nagrodę ufundowałem w roku 1957 dla uczczenia mojej towarzyszki życia, poetki Almy Johanny Koenig, zamordowanej przez hitlerowców w 1942 roku. Sytuacja wówczas była zupełnie inna niż dziś. Pisarzom powodziło się bardzo źle. Wielu z nich musiało zrezygnować z własnej produkcji, aby zarabiać na życie. Chciałem coś z tej dobroci serca, z tego koleżeństwa, które cechowały Almę, przekazać żyjącym autorom. Choćby temu jednemu autorowi, który co pięć lat miał szansę zdobycia nagrody (...). Dziś sytuacja zupełnie się zmieniła. Młodym autorom powodzi się względnie dobrze. Dziś już nie tylko państwo i gminy większych miast, ale też liczne stowarzyszenia prywatne przyznają nagrody literackie. Ba, każdy szanujący się bank bawi się $\mathrm{w}$ protektora sztuki i literatury, wobec tego tylko jeszcze $\mathrm{z}$ wewnętrznego zobowiązania kontynuuję pracę zaczętą $\mathrm{w}$ dobrej intencji. I chyba skończę w roku 1987, a więc w setną rocznicę urodzin Almy (...). W kilku wypadkach udało się dzięki tej nagrodzie wyrobić laureatowi pewną renomę, coś w rodzaju odskoczni dla jego kariery. Tak było na przykład w przypadku Bobrowskiego, wobec tego dziś Alma Johanna Koenig-Preis, mimo że finansowo nie może się równać z wieloma innymi nagrodami, ma bardzo dobrą opinię. Jej przyznanie uchodzi w fachowych kołach bezwzględnie za zaszczyt"18.

Wiele czasu poświęca także Oskar Jan Tauschinski pracy w jury ds. stypendiów dla młodych pisarzy, działając na zlecenie Ministerstwa Oświaty i Sztuki.

Ważnym epizodem w literackiej biografii wiedeńskiego pisarza była przyjaźń ze Stanisławem Jerzym Lecem, przebywającym w latach 1947-1950 w Polskiej Misji Wojskowej w Wiedniu jako attache kulturalny. Tłumaczenia wierszy i aforyzmów Leca autorstwa Tauschinskiego i Helene Lahr były pierwszymi translacjami na język niemiecki polskiego autora, przekłady te zapoczątkowały - jak stwierdza Roman Taborski - „błyskotliwą karierę zagraniczną twórczości poetyckiej Leca ${ }^{19}$. Oskar Jan Tauschinski wielokrotnie pisał o Lecu z sympatią i uznaniem ${ }^{20}$, wspomi-

${ }_{18}$ Nie chce się nudzić przy pracy... Rozmowa z Oskarem Janem Tauschinskim, rozm. K.A. Kuczyński, Życie Literackie, 1984, nr 24, s. 11.

${ }_{19}$ R. Taborski, Wśród wiedeńskich poloników..., s. 216.

${ }^{20}$ Np.: O. J. Tauschinski, Stanistaw Jerzy Lec we wspomnieniach jego tłumaczy [w:] Myśle 
nał go w swych licznych wystąpieniach publicznych, jak np. w 1979 roku podczas uroczystości jubileuszu XX-lecia istnienia Towarzystwa Polsko-Austriackiego: „,...(była to) jedna z najbardziej chyba oryginalnych umysłowości wśród pisarzy polskich owego okresu. W przeciągu kilku krótkich lat, w których pełnił urząd attache kulturalnego, Lec w zadziwiającym stopniu pozyskał w wiedeńskich kręgach literackich sympatię i zainteresowanie dla piśmiennictwa polskiego. Jego poziom intelektualny, szerokość horyzontów i talent dyplomatyczny zjednały Polsce na terenie Austrii wielu szczerych przyjaciół"21.

Przyjaźń ze Stanisławem Jerzym Lecem jest tylko jednym z wielu przykładów kontaktów Oskara Jana Tauschinskiego z twórcami polskimi, lata następne to okres intensywnej nierzadko współpracy z wydawcami, uczonymi i pisarzami, by jako przykład wymienić fakt, że utwór wiedeńskiego autora Sakrileg ukazał się naprzód w języku polskim, a dopiero w kilka lat później w niemieckim, i należy tutaj podkreślić, że „polskie wydanie w tłumaczeniu Stefana H. Kaszyńskiego odegrało chyba decydującą rolę" 22 . Oskar Jan Tauschinski wielokrotnie gościł w Polsce prezentując swoją twórczość, brał też udział w konferencjach naukowych, organizowanych przez polskich germanistów ${ }^{23}$.

W roku 1970 Oskar Jan Tauschinski otrzymał decyzją Prezydenta Republiki Austrii tytuł profesora, będący wyrazem uznania za wartości wniesione w rozwój kultury austriackiej, Tauschinski jest laureatem wielu nagród i wyróżnień - także polskich - aby wspomnieć tutaj m.in.: Anerkennungspreis im Namen des österreichischen Staatspreises (1952), Preis der Stadt Kapferberg (1953), Preis der Kurt-Desch-Stiftung (1953), Preis des Theodor-Körner-Stiftungsfonds (1955), Prämiierung im Rahmen des Deutschen Jugendbuchpreises (1956), Förderungspreis der Stadt Wien (1957), Österreichischer Staatspreis für Jugendliteratur (1957), Preis des Theodor-Körner-Stiftungsfonds (1961), Jugendpreis der Stadt Wien (1962), Österreichischer Staatspreis für Jugendliteratur (1962), Kinderbuchpreis der Stadt Wien (1969), Österreichischer Staatspreis für Kinderliteratur (1969-1970), Übersetzerpreis - im Rahmen des Österreichischen Staatspreises für Jugendliteratur - (1971), Order "Zasłużony dla Kultury polskiej“ (1971), nagroda Polskiego Ośrodka Stowarzyszenia Kultury Europejskiej - SEC (1977), Verdienstkreuz für Wissenschaft und Kunst I. Klasse (1979).

więc jestem.... Stanisławie Lecu, oprac. W. Leopold, Kraków 1974.

${ }_{21}$ O. J. Tauschinski, Polsko-austriackie kontakty literackie po II wojnie światowej, Austria-Polska, 1980, nr 1, s. 57.

${ }^{22}$ Nie chce się nudzić przy pracy..., op, cit., s. 11.

${ }^{23}$ K. A. Kuczyński, Polsko-austriackie stosunki literackie, Języki Obce w Szkole, 1978, nr 2, s. 122-123. 
Duże zasługi położył Oskar Jan Tauschinski jako edytor spuścizny literackiej Almy Johanny Koenig, Heleny Lahr oraz Marlen Haushofer, jak sam mówi o tym, „,inni będą musieli ocenić, czy moje wysiłki przeforsowania ich nazwisk w literaturze były sensowne. W przeciągu 38 lat wydałem wszystkie za życia Almy nie drukowane dzieła, a także wiele wznowień już publikowanych. Opublikowałem objętościowo niewielką spuściznę Helenę Lahr, która jako autorka jest publiczności prawie nie znana, ale wśród znawców wysoce ceniona. Haushofer, która zmarła w 1970 roku, w swym testamencie wyraziła życzenie, abym zajął się opublikowaniem jej dzieł"24.

Oskar Jan Tauschinski, mieszkający na stałe w Wiedniu od roku 1933, był pisarzem austriackim, ale jego zainteresowanie sprawami Polski i Polaków, jego przychylna postawa wobec naszego kraju, prezentowana zarówno w jego utworach, jak i w kontaktach bezpośrednich ${ }^{25}$, pozwala widzieć $\mathrm{w}$ nim nie tylko wybitnego twórcę, ale i „przyjaciela polskiego słowa", jak to niegdyś trafnie wyraził Jan Koprowski².

Dodać warto, że brat Oskara Jana Tauschinskiego, Robert mieszkał w Warszawie od lat międzywojennych, ukończywszy wydział architektury na Politechnice Gdańskiej. Jako architekt brał udział w odbudowie Gdańska, jego żoną była córka znanego historyka warszawskiego, profesora Olgierda Górki. Rodzice Oskara Jana Tauschinskiego wojnę przeżyli w Warszawie, następnie zamieszkali w Krakowie.

W swych utworach oryginalnych - jak było wspomniane - zawarł Oskar Jan Tauschinski liczne poloniki, np. w powieści Wer ist diese Frau ?27, utworze biograficznym o Marii Curie-Skłodowskiej, mikropowieści Sakri$\operatorname{leg}^{28}$, w kilku opowiadaniach, jak np. Zur Traube ${ }^{29}$ oraz Delfina singt ${ }^{30}$, czy w tomie polskich podań i baśni ludowych Der Jüngling im Baumstamm ${ }^{31}$.

${ }^{24}$ Nie chcę się nudzić przy pracy..., s. 11.

${ }^{25}$ K.A. Kuczyński, O twórczości austriackiego polonofila i polskiego germanisty. Z nieznanymi listami Oskara Jana Tauschinskiego do prof. Stefana H. Kaszyńskiego, Studia Niemcoznawcze Uniwersytetu Warszawskiego, t. XXXIII, 2006.

${ }^{26}$ J. Koprowski, Przyjaciel polskiego stowa [w:] U nas i gdzie indziej, Katowice, 1975, s. 101.

27 O.J. Tauschinski, Wer ist diese Frau? Biographisches Jugendbuch über Madame Curie, Recklinghausen 1955 (oraz Wien 1957, München 1972, Wien-München 1983). Książka została przetłumaczona na holenderski, szwedzki, japoński i grecki oraz otrzymała Deutscher Jugendbuchpreis 1956, jak i Austriacką Nagrodą Państwową w 1957 roku.

28 O. J. Tauschinski, Sakrileg, Berlin 1983.

29 OJ. Tauschinski, Zur Traube [w:] Der Eisstoß, Wien-München 1972, 1983.

30 O. J. Tauschinski, Delfina singt [w:] Zwielichtige Geschichten, Wien 1957.

${ }_{11}$ O. J. Tauschinski, Der Jüngling im Baumstamm, Wien 1969. Książka uzyskała Nagrodę Miasta Wiednia (1969) oraz Austriacką Nagrodę Państwową (1970). Została także przetłumaczona na język Afrikaans. 
W swoich odczytach, jak np. podczas wystąpienia w 1973 roku w Czytelni Polskiej w Wiedniu (obecnie Instytut Polski - przyp. KAK), kiedy mówił o Tadeuszu Rittnerze, propaguje życie i twórczość polskich twórców ${ }^{32}$.

Pochodząc z ziem leżących na styku dwóch kultur, nabył Tauschinski nie tylko umiejętności językowych, ale także nauczył się rozumieć i cenić dorobek dziejowy narodu polskiego. Umiejętności te zaowocowały po wojnie w postaci sporej ilości tłumaczeń polskich utworów. Raz jeszcze powróćmy do powinowactw i przyjaźni ze Stanisławem Jerzym Lecem, jakże ważnej dla obu twórców.

W szkicu poświęconym sylwetce wiedeńskiego polonofila przytacza Stefan H. Kaszyński, czołowy polski znawca twórczości Oskara Jana Tauschinskiego, genezę jego translatorskich zainteresowań: „Ówczesny polski attache Stanisław Jerzy Lec nakłania go do podjęcia się trudu przyswajania Austriakom literatury polskiej. Pierwsze tłumaczenia Tauschinskiego powstają przy współudziale wiedeńskiej poetki Heleny Lahr, są to przede wszystkim wiersze, no i znakomite aforyzmy Leca"33.

Dzieje przyjaźni Stanisława Jerzego Leca i Oskara Jana Tauschinskiego nie zostały jeszcze opracowane, wydaje się jednak, że był to okres ważny dla nich obu ${ }^{34}$. Jest także faktem, że Lec był tłumaczony i popularyzowany w Austrii znacznie wcześniej, niż miało to miejsce w Republice Federalnej Niemiec, kiedy to naszego poetą zaczął na wielką skalę propagować inny translator, Karl Dedecius, uważany obecnie - słusznie zresztą - za „odkrywcę" wielu czołowych polskich twórców, nieznanych na terenie Republiki Federalnej Niemiec. Szczególnie cenne są dokonania Karla Dedeciusa w zakresie przyswajania językowi niemieckiemu wierszy współczesnych poetów polskich. Jest jednak zasługą Heleny Lahr i Oskara Tauschinskiego, że jako pierwsi docenili wielki kunszt poetycki naszego aforysty.

W latach osiemdziesiątych, po okresie mniejszej aktywności translatorskiej, wydaje Tauschinski tłumaczenie Raportu z oblężonego miasta Zbigniewa Herberta (1985), będące doskonałym przykładem jego umiejętności ${ }^{35}$.

${ }^{32}$ Odczyt o Rittnerze został wydrukowany w numerze specjalnym periodyku „Österreichsische Osthefte" (1974, Sonderdruck), organie Österreichisches Ost und Südosteuropa-Institut, wydanym z okazji wizyty ówczesnego premiera PRL Piotra Jaroszewicza w Austrii.

33 S. H. Kaszyński, Posłowie..., s. 84.

34 Por. m.in.: O. J. Tauschinski, Stanisław Jerzy Lec we wspomnieniach tłumacza [w:] Myślę, że jestem...; K. Dedecius, Polnische Profile, Frankfurt/M., 1975, s. 121.

${ }_{35}$ Z. Herbert, Bericht aus einer belagerten Stadt und andere Gedichte, Frankfurt/ Main 1985. 
Jakkolwiek Oskar Jan Tauschinski przetłumaczył na niemiecki sporą ilość wierszy (drukowanych przede wszystkim w czasopismach, jak np. „Podium” czy „Literatur und Kritik”), a m.in. utwory Barańczaka, Białoszewskiego, Bieńkowskiego, Brylla, Grochowiaka, Harasymowicza, Herberta, Karpowicza, Przybosia, Różewicza, Szymborskiej oraz kilka sztuk teatralnych, jak Jerzego Broszkiewicza Koniec księgi szóstej, Bohdana Drozdowskiego Hardy, Romy Ligockiej Dwa razy południe, to jednak gros uwagi poświęcił prozie, w pierwszej zaś kolejności utworom o tematyce młodzieżowej.

I tak z jego przekładów prozatorskich wymieńmy Wielki Tydzieńn ${ }^{36}$ Jerzego Andrzejewskiego, powieść wydaną w Wiedniu już w roku 1948, a następnie wznowioną w jednym z wydawnictw Niemieckiej Republiki Demokratycznej. Z pozycji tegoż autora przełożył Oskar Jan Tauschinski jeszcze dwie inne powieści, a mianowicie Ciemności kryją ziemię oraz Ład ser$\mathrm{ca}^{37}$. Lista jego dalszych tłumaczeń jest dosyć obszerna, aby przytoczyć tutaj takie książki jak Leopolda Tyrmanda Siedem dalekich rejsów ${ }^{38}$, Leo Lipskiego Piotruśs $^{39}$, Ireny Tuwim Marek Wagarek ${ }^{40}$, Joanny Kulmowej Wio, Leokadio ${ }^{41}$, Janusza Domagalika Koniec wakacji i Zielone kasztany ${ }^{42}$, (za tłumaczenie Janusza Domagalika otrzymał Oskar Jan Tauschinski Austriacką Nagrodę Państwową ${ }^{43}$ ), Adama Bahdaja Uwaga, czarny parasol! ${ }^{44}$, Konrada Grudy Zwölf Uhr einundvierzigis czy Kazimierza Dębnickiego Kot na suficie ${ }^{46}$.

W swym dorobku translatorskim posiadał jeszcze tłumaczenie wersji scenicznej Ciemności kryją ziemię Jerzego Andrzejewskiego ${ }^{47}$, współudział w tłumaczeniu niektórych utworów Mickiewicza ${ }^{48}$ oraz dosyć liczne,

\footnotetext{
36 J. Andrzejewski, Die Karwoche, Wien 1948, Dresden 1950.

37 J. Andrzejewski, Finsternis bedeckt die Erde, München 1961; tenże, Ordnung des Herzens, München 1970.

${ }^{38}$ L. Tyrmand, Ein Hotel in Darłowo, Berlin (W) 1962.

${ }^{39}$ L. Lipski, Piotruś. Ein Apokryph, Neuwied 1967.

${ }^{40}$ I. Tuwim, Der Schwanzer-Heinz, Wien 1965.

${ }^{41}$ J. Kulmowa, Hüh, Leokadio, Wien 1967.

42 J. Domagalik, Ich habe mich entschieden, Wien 1971, 1978 oraz Grüne Kastanien, Wien-München 1979. 1971.

43 Übersetzerpreis im Rahmen des Österreichischen Staatspreises für Jugendliteratur

${ }^{44}$ A. Bahdaj, Der Fall: Schwarzer Regenschirm, Wien 1974.

${ }^{45}$ K. Gruda, Zwölf Uhr einundvierzig, Wien 1975. Pozycja ta nie ukazała się drukiem w języku polskim.

${ }^{46}$ K. Dębnicki, Die Katze an der Zimmerdecke, München 1975.

47 J. Andrzejewski, Finsternis bedeckt die Erde. Bühnenfassung, Wien 1966.

${ }^{48} \mathrm{~Np}$. w ramach pozycji: Adam Mickiewicz, der große Dichter der polnischen Nation. Festschrift zur Feier des 100. Todestages, Wien 1955, do której dostarczył filologicznego przekładu, dokonanego następnie w artystycznej formie przez Helenę Lahr.
} 
drobne pozycje prozatorskie (np. Ważyka, Kuśniewicza), rozsiane po antologiach i czasopismach literackich.

Przy analizie dorobku Tauschinskiego - tłumacza należy także wziąć pod uwagę fakt, że przekłady literackie nie były podstawowym jego zajęciem. I tak w liście do autora tego tekstu pisał Oskar Jan Tauschinski m.in.: „W głównym zawodzie, z którego żyję, jestem redaktorem technicznym w instytucji ,Österreichischer Buchklub der Jugend'. W drugim zawodzie piszę, a dopiero $\mathrm{w}$ trzecim pracuję jako tłumacz z polskiego..." 49

Nie ilość stanowiła więc o randze Oskara Jana Tauschinskiego wśród tłumaczy literatury polskiej na język niemiecki. Jednym z poważnych dowodów uznania dla jego kunsztu translatorskiego było ukazywanie się książek w jego tłumaczeniu w Republice Federalnej Niemiec, Berlinie Zachodnim i Niemieckiej Republice Demokratycznej, a więc w krajach (RFN, NRD), gdzie nie brakowało tłumaczy o doskonałych kwalifikacjach, aby wspomnieć tutaj przykładowo Karla Dedeciusa, Klausa Staemmlera, Josefa Hahna, Heinricha Kunstmanna, Waltera Thiela, Henryka Bereskę, Caesara Rymarowicza czy Kurta Kelma.

Przekład dzieł literatury polskiej na język niemiecki był pasją Oskara Jana Tauschinskiego, jego działalność przysparzała odbiorcy niemieckojęzycznemu wiele wartościowych pozycji, pozwalała w coraz lepszym stopniu poznawać dorobek polskiej kultury.

Oskar Jana Tauschinski zmarł 14 sierpnia 1993 w Wiedniu.

$$
* * *
$$

Przypadająca w 2014 roku sto dwudziesta rocznica urodzin Heleny Lahr, autorki utworów poetyckich i prozatorskich, tłumaczki m.in. z języka polskiego, jest sprzyjającą okazja, aby przypomnieć tę nad wyraz interesującą i godną uwagi postać.

Helene Lahr (właściwe nazwisko Birti-Lavarone) urodziła się 9 stycznia 1894 roku w Wiedniu, w zamożnej rodzinie mieszczańskiej jako córka Adolfa Obermayera (siostrą jego była poetka Rosa Meyreder). Przyszła pisarka i tłumaczka miała więc od wczesnej młodości kontakt ze sztuką której też pozostała wierna do końca życia. Wiersze, przypominające czasem w nastroju liryki Heinricha Heinego, pisać zaczęła już jako kilkunastoletnia dziewczyna. Już wówczas musiała wykazywać pewne uzdolnienia, gdyż zyskała pochlebną opinię u Fritza von Herzmanowsky'ego - Orlando.

W roku 1914 poślubiła oficera c.k. kawalerii Franza Birti, spędzając lata wojny w pobliżu frontu wschodniego, na terenach Polski, Rumunii

${ }^{49}$ List Oskara Jana Tauschinskiego do autora tekstu z dnia 12.10.1976. 
i Węgier. W okresie 1918-1945 mieszkała Helene Lahr w Baden, nie zaliczając jednak tych lat do szczęśliwych. W początkach lat dwudziestych, $\mathrm{w}$ dużej mierze dzięki zachętom poety Ernsta Lissauera, powraca Lahr do twórczości poetyckiej.

W roku 1945 decyduje się Helene Lahr na powrót do rodzinnego Wiednia. Lata powojenne stanowią przełom w jej dotychczasowym życiu. Rozpoczyna pracę zawodową jako redaktor w jednym z wiedeńskich wydawnictw, zajmuje się także intensywnie tłumaczeniami utworów lirycznych z trzech literatur: amerykańskiej, francuskiej i polskiej.

Duże zasługi położyła Helene Lahr jako tłumaczka z literatury polskiej, chociaż języka polskiego nie znała. Był jej tutaj pomocny Oskar Jan Tauschinski.

Do największych osiągnięć translatorskich Heleny Lahr należy jej pionierska działalność w zakresie „odkrywania” dla niemieckojęzycznego czytelnika nowych połaci literatury polskiej. I tak do jej zasług zaliczyć należy wylansowanie wielkiej twórczości przebywającego wówczas na placówce dyplomatycznej w Wiedniu Stanisława Jerzego Leca. Przy współudziale Oskara Jana Tauschinskiego przyswaja Lahr austriackiemu odbiorcy wiersze i aforyzmy naszego poety.

Helene Lahr rozpoczęła prace nad przekładem twórczości Lecą już $\mathrm{w}$ latach czterdziestych, a więc na wiele lat przed Karlem Dedeciusem, wydającym i propagującym autora Myśli nieuczesanych w Republice Federalnej Niemiec. Można bez przesady stwierdzić, że Helene Lahr jako pierwsza z zagranicznych tłumaczy doceniła klasę Stanisława Jerzego Leca i otworzyła mu swymi znakomitymi przekładami drogę do zawrotnej kariery światowej. Wybór utworów Leca pt. Über Brücken schreitend ukazał się w Wiedniu w roku $1950^{50}$. Antologia została poprzedzona przedmową pióra wielkiego przyjaciela Polski i Polaków, Franza Theodora Csokora.

Lata pięćdziesiąte przynoszą dwie dalsze pozycje $\mathrm{z}$ warsztatu translatorskiego wiedeńskiej poetki, które ugruntowały jej pozycję dobrego znawcy literatury polskiej i doskonałej tłumaczki. I tak w roku 1953 ukazuje się cenna antologia Polnische Lyrik ${ }^{51}$, zawierająca utwory 22 poetów polskich, będąca jednocześnie jednym z pierwszych tomów zbiorowych literatury polskiej po roku 1945 na terenie niemieckiego obszaru językowego.

W Roku Mickiewiczowskim (1955) publikuje Helene Lahr, w tomie znanego slawisty wiedeńskiego Gunthera Wytrzensa, poświęconym pamięci naszego Wieszcza Adam Mickiewicz, der große Dichter der polnischen Nation (Festschrift zur Feier des 100. Todestages) garść przekładów ${ }^{52}$. Pozycja

\footnotetext{
50 Über Brücken schreitend. Gedichte, über. von H. Lahr, Wien 1950.

51 Polnische Lyrik. Nachdichtungen von Helene Lahr, Wien 1953.

52 Adam Mickiewicz, der große Dichter der polnischen Nation. Festschrift zur
} 
zawiera wybór szczególnie cennych utworów i jest jednym z dowodów dużego zainteresowania Mickiewiczem w świecie.

W okresie późniejszym, w drugiej połowie lat 50., Helene Lahr tłumaczy utwory Juliana i Ireny Tuwimó $w^{53}$, Juliusza Słowackiego ${ }^{54}$, Jana Brzechwy $^{55}$ i Janiny Porazińskiej ${ }^{56}$. Była surową wobec siebie i krytyczną translatorka, tym też należy tłumaczyć, że jej dorobek przekładowy nie jest ilościowo duży. Jednak ogrom pracy włożony w proces przetwarzania polskiego wiersza na niemiecki wydał się owoce w postaci doskonałej jakości, jak i związanej z tym dużej popularności przełożonych utworów.

Helene Lahr pisała także utwory oryginalne. Za jej życia opublikowany został tom wierszy i opowiadan Die wirklichen Eulen ${ }^{57}$, natomiast pośmiertnie ukazały się dwie pozycje (w opracowaniu Oskara Jana Tauschinskiego): tom wierszy Skeptisches Tagebuch ${ }^{58}$ oraz wybór wierszy, opowiadań, szkiców i esejów Der Seitenblick ${ }^{59}$.

Mimo długoletniej choroby twórczość Helene Lahr emanuje uśmiechem i pogodą ducha, czytelnik nie domyśliłby się, że autorka przez wiele lat przykuta była do fotela. Także w swej pracy przekładowej wiele uwagi poświęciła tłumaczeniu lekkich, pogodnych utworów dziecięcych.

W swym ilościowo niepokaźnym, lecz interesującym dorobku, posiada Helene Lahr także garść aforyzmów. A oto jeden z nich:

Gdybyż miłość była tak słodka, jak ją o to posądza zazdrość ${ }^{60}$.

Wrażliwość poetycka, subtelność natury, a jednocześnie dzielność charakteru przeciwko przeciwnościom losu, każe przed tą niecodzienną kobietą chylić czoło. Czynna, mimo choroby, do ostatnich chwil, zmarła w swym rodzinnym, ukochanym Wiedniu 23 marca 1958 roku. Za życia ujrzała w druku niewiele swoich utworów, jednak ich wartość, przede wszystkim przekładów, chociaż i jej twórczość oryginalna warta jest uwa-

Feier des 100. Todestages. Text: G. Wytrzens, Nachdichtungen H. Lahr, Wien 1965.

${ }^{3}$ J. Tuwim, Die Lokomotive, Köln 1958; I. Tuwim, Der Schwänzer-Heinz (z O. J. Tauschinskim), Wien 1965.

54 J. Słowacki, Vom Hänschen, das den Hunden Schuhe nähte. Kinderballade, Warschau 1958.

55 J. Brzechwa, ZOO. Kinderverse, München 1969; Die Krähe und der Schweizerkäse, Köln 1959.

56 J. Porazińska, Bärbel und die Krähe. Kinderbuch, München 1959.

57 Die wirklichen Euglen. Geschichten und Gedichte, Wien 1955.

58 Skeptisches Tagebuch. Gedichte aus dem Nachla $\beta$, Wien 1963.

${ }^{59}$ Der Seitenblick. Gedichte, Skizzen und Essays aus dem Nachla $\beta$, Wien 1969.

${ }^{60}$ Wäre die Liebe doch so sü $\beta$, wie die Eifersucht glaubt (tłum. K.A.K.), [w:] Der Seitenblick, op. cit, s. 33. 
gi, zasługuje na uznanie i lepszą niż dotąd znajomość w Polsce, której oddała swoje umiejętności i uczucia.

Oskar Jan Tauschinski oraz Helen Lahr byli gorącymi entuzjastami literatury polskiej, ich przekłady pozwoliły austriackiemu czytelnikowi poznać wiele wartościowych dzieł naszych autorów.

\section{II}

Wśród powojennych polonofilów austriackich Gerda Leber-Hagenau zajmowała ważne miejsce, była pisarką historykiem, tłumaczką i wydawcą w jednej osobie. Od końca lat czterdziestych poświęcała wiele wysiłku propagowaniu kultury polskiej nad Dunajem, za co została wyróżniona cenionymi nagrodami i odznaczeniami, jak m.in. medalem "Zasłużony dla kultury polskiej", nagrodą im. Alfreda Jurzykowskiego, nagrodą Polskiego PEN-Clubu czy "Złotą Odznaką Zasługi dla PRL”, nagrodą im. Andreasa Gryphiusa, wyróżnieniem Amicus Poloniae. W 1970 roku został jej przyznany przez Prezydenta Republiki Austrii tytuł profesora za zasługi na polu kultury ${ }^{61}$.

Dawne dzieje rodzinne łączyły ją z alzackimi Hugenotami. Jeden z nich, żołnierz napoleoński ranny nad Berezyną, wycofując się z Rosji trafił na osadę niemieckich kolonistów z Baden założoną na ziemiach polskich koło Łodzi. Los sprawił, że ów przodek pozostał na zawsze w Polsce i odtąd będąc właścicielem jednej z największych w kraju fabryki wyrobów glinianych dał początek linii, z której bezpośrednio wywodzi się bohaterka niniejszego szkicu.

Gerda Hagenau urodziła się w Łodzi 11 grudnia 1918 roku w niemieckiej, nie spolonizowanej rodzinie. Jak sama wspominała, „chociaż w domu mówiłam po niemiecku, chodziłam do niemieckiej szkoły - poznałam i pokochałam literaturę waszego kraju"62.

W niepublikowanych jeszcze wspomnieniach przywołuje okres swojej młodości w okresie międzywojennym, pisze o trudnych krokach w poznawaniu języka polskiego, o nie zawsze łatwych kontaktach z młodzieżą i nauczycielami: „Było to dla mnie strasznym szokiem, gdy siedząc w pierwszej klasie naszego Niemieckiego Prywatnego Gimnazjum w Łodzi na lekcji języka polskiego nic nie rozumiałam. Dosłownie, nic. Słowa szumiały w moich uszach jak lasy Kraszewa, Rąbienia, jak falujące pola

${ }^{61}$ Por. D. Kucharska, Gerda Leber-Hagenau. Austriacka popularyzatorka kultury polskiej, Łódź 2005.

${ }^{62}$ G. Leber-Hagenau, Słowo na eksport, „Kobieta i Życie”, 1975, nr 43, s. 11. 
złotej pszenicy, jak suchy piasek, który osypywał się szeleszcząc i skrzypiąc po kołach naszego landauera, tak sypały się słowa polskie w moich uszach. To były trudne czasy..." ${ }^{\prime 6}$.

W innym miejscu Gerda Hagenau wspomina swój pierwszy sukces w szkole związany z literatura, polską z dziełem Adama Mickiewicza, twórcy, którego w późniejszych latach niejeden utwór przełożyła na język niemiecki. Jak pisze Hagenau, „mieliśmy wspaniałego polskiego nauczyciela, doktora Kalisza. Dużo wymagał. Ja prawie zawsze dostawałam ledwie trójkę. Ale pewnego dnia stało się coś niespodziewanego. Dr Kalisz oddał nam zeszyty z ostatniej klasówki, której temat brzmiał «Przyroda w Panu Tadeuszu». Dr Kalisz był jakoś wzruszony, gdy mówił, że mamy w klasie jedna, która tak bardzo autentycznie, kongenialnie po prostu odczuwa piękno Mickiewiczowskiego języka, opisującego przyrodę w Panu Tadeuszu. Ja nie bardzo uważałam na to, co on tam mówił, ale nagle oddał mi mój zeszyt. Czuję jeszcze po dziś dzień, jak się zarumieniłam, cała fala mnie oblała. W zeszycie stała wielka piątka - za treść. Za formę, oczywiście - trójka z minusem. Ale to nic. To było przełomowym przeżyciem w moim stosunku do języka polskiego, do polskiej literatury ${ }^{64}$.

Gerda Leber-Hagenau wyjeżdża w roku 1942 do Austrii. Wkrótce rozpoczyna studia w Wiedniu, „wchłaniałam wszystko, co mnie interesowało, z wielką intensywnością (...) wielkimi haustami po prostu odurzyłam się kultura, i wiedzą starego cesarskiego miasta Habsburgów. Studiowałam i historię sztuki, i historię teatru, i nawet kilka semestrów muzykologię, i germanistykę, i slawistykę, i egiptologię"65.

W ramach studiów slawistycznych zajęła się Gerda Leber-Hagenau szczególnie literaturą polska, wygłaszając m.in. na seminarium Rudolfa Jagoditscha referat o Wyspiańskim. W swych wspomnieniach pisze: „Rozmawiałam z moim profesorem Jagoditschem, który wykładał literatury słowiańskie. Sugerowałam mu, że chciałabym studiować polską literaturę i opracować na ten temat referaty, bo po polsku umiałam chyba lepiej - mimo trójki minus - niż on, i to było oczywiście dla mnie bardzo wygodne. Zgodził się. Mój pierwszy referat miałam o Reju o jego Żywocie człowieka poczciwego. Drugi referat o Wyspiańskim. Wtedy pierwszy raz próbowałam tłumaczyć z polskiego. Przetłumaczyłam kilka scen z Warszawianki (...) ten referat wygłosiłam przed pełną salą w Instytucie Slawistyki

${ }^{63}$ G. Leber-Hagenau, Moi przyjaciele - Polacy, maszynopis, Wiedeń 1990, s. 3 [w posiadaniu autora]. Por. także tom grupujący prace o życiu i twórczości wiedeńskiej autorki: Gerda Leber-Hagenau a stosunki polsko-austriackie w XX wieku, pod red. K.A. Kuczyńskiego i D. Kucharskiej, Toruń-Płock 1998.

64 Ibidem, s. 4.

65 Ibidem, s. 7. 
na Uniwersytecie Wiedeńskim, nie istniała oficjalnie w ogóle polska literatura, i tego samego dnia, gdy ja z wielkim entuzjazmem wygłosiłam referat o Wyspiańskim i czytałam z jego Warszawianki, szalało w Warszawie powstanie w getcie! Po moim wykładzie studenci przyszli do mnie i pytali, gdzie można te tłumaczenia dostać, nie wiedzieli, że istnieje taka wspaniała literatura polska" ${ }^{\prime 66}$.

Swoją rozprawę doktorską poświęciła Gerda Leber-Hagenau teatralnym dziejom Dziadów, powracając do swych wczesnych fascynacji utworami Mickiewicza. Teatr stawał się zresztą wielką miłością Gerdy Leber-Hagenau, tym bardziej, że „w roku 1942 czy 43 został założony Instytut Teatrologii przez prof. Kindermanna. Ja byłam od pierwszej godziny na wszystkich wykładach. I też prof. Kindermann zaraz zaakceptował moje polskie zainteresowania, bo sam będąc przez kilka lat profesorem w Gdańsku, znał fluktuujące kulturalne związki niemieckiej i polskiej kultury. I tak doszło do tego, że moją pracę doktorską pisałam o Dziadach Mickiewicza, o dramacie i inscenizacjach. Do tego celu przetłumaczyłam Dziady, i oczywiście dołączyłam spory tom z fotografiami różnych przedstawień, z których wtedy najsłynniejsze było Leona Schillera..."67.

Zbliżał się rok 1945. Gerda Hagenau mieszka teraz w Thumersbach w Alpach, w pobliżu Salzburga. Wychodzi za mąż, ale szczęśliwym trafem - dzięki namowom męża - nie traci kontaktu z literaturą polską. Od przebywającego wówczas po wojnie w Wiedniu Stanisława Jerzego Lecą otrzymuje nowości wydawnicze, to jej pierwsze kontakty po wojnie z polską literaturą. Warto tutaj przytoczyć słowa Gerdy Leber-Hagenau, że jeszcze w latach czterdziestych „sugerował mi mój mąż, ażebym pisała artykuły o polskiej literaturze w różnych gazetach w Wiedniu i Salzburgu. Więc pisałam o moim tak bardzo uwielbianym Mickiewiczu i jego stosunkach do Goethego, pisałam o Chopinie, o Wyspiańskim itd. Zaczęto się orientować, że trochę się znam na Polsce, i tak chyba doszło do tego, że Burgtheater prosił mnie w roku 1956, abym lektorowała wszystkie sztuki polskie, które zostały nadesłane z Polski na konkurs dramatów w Bregenz. Polska pierwszy raz po wojnie mogła brać udział w takiej imprezie, było to po polskiej wiośnie" ${ }^{\prime \prime 6}$.

Tak więc debiut Gerdy Leber-Hagenau nastąpił w roku 1948 w postaci artykułu Goethe und Mickiewicz na łamach cenionego tygodnika katolickiego „Die Furche”69. Z czasem nastąpiły dalsze, coraz liczniejsze artykuły i szkice, np. W „Wiener Tageszeitung”, ,Salzburger Nachrichten”

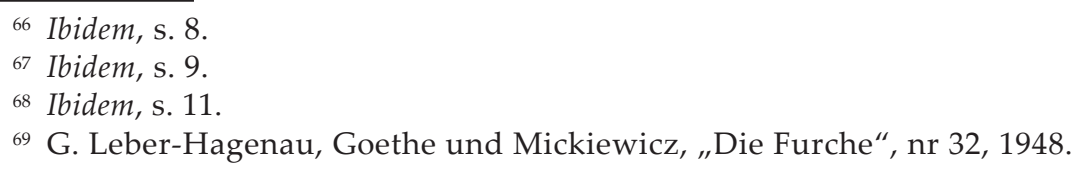


czy „Maske und Kothurn”70. Coraz częstsze były także wystąpienia Gerdy Leber-Hagenau na forum publicznym, czy to w postaci odczytów, czy na falach eteru.

Działalność na polu krytyki literackiej i teatralnej, to jedno z pierwszych pól działalności Gerdy Leber-Hagenau. W kolejnych latach ogłasza ona artykuły m.in. o Marii Dąbrowskiej, Romanie Brandstaetterze, Kazimierzu Dejmku, polskiej komedii czy o współczesnej literaturze i teatrze polskim w Wiedniu ${ }^{71}$.

Jakkolwiek Gerda Leber-Hagenau uważała, że „przede wszystkim czuje się pisarką i uczona, tłumaczenia zaś powstają nieco na uboczu mojej głównej pracy"72, to jednak wydaje się, że jednak w dziedzinie przekładu polskiej literatury zasłużona polonofilka osiągnęła swoje największe sukcesy, tłumacząc na język niemiecki utwory ponad siedemdziesięciu polskich pisarzy.

O dużym wpływie literatury romantycznej na jej upodobania artystyczne i dalszą drogę literacką mówiła Gerda Leber-Hagenau wielokrotnie $^{73}$, tutaj też odniosła duże sukcesy translatorskie, tłumacząc m.in. Dziady, Księgi narodu polskiego i pielgrzymstwa polskiego czy Anhelli. Niektóre z nich przystosowane zostały do adaptacji scenicznej. Niestety większość z tych utworów nie ukazała się drukiem (poza Dziadami w 1990 roku), jak tłumaczyła to sama autorka przekładów „muszę ze smutkiem podkreślić, że klasyka polska jest ciągle nie doceniana na Zachodzie. Przekłada się stanowczo za mało w stosunku do rangi dawnej literatury polskiej"74.

O swych nadziejach na ujrzenie np. Dziadów we własnym tłumaczeniu na scenie w Austrii, wspomina także Gerda Leber-Hagenau w cytowanych już wspomnieniach: „,...robiłam adaptacje Dziadów dla teatru, bo radziłam się, że będę mogła ulokować to arcydzieło w jakimś teatrze niemieckim albo austriackim, był przecież aktualny ten temat, bo akurat wtedy były Dziady Dejmka w Teatrze Narodowym w Warszawie tą wielką sensacją

${ }^{70}$ Por. m.in.: Zwischen Ost und West. Profile polnischer Dichter, „Salzburger Nachrichten“ 25.6.1949; Chopin in Wien, „Wiener Tageszeitung“, 25.9.1949; Slawen und Goethe, "Salzburger Nachrichten", 1949; Frührot der Freiheit. Zum 100. Todestag von Adam Mickiewicz, "Salzburger Nachrichten“ 2.12.1955; Das Schweigen gebrochen. Zur literarischen Situation in Polen, „Salzburger Nachrichten“ 7.5.1957.

${ }^{71}$ Por.m.in.: Maria Dąbrowska im Spiegel der deutschsprachigen Presse, "Österreichische Osthefte“ 1962; Roman Brandstaetter, „Deutsche Studien“ nr 26, 1969; Noch ist Polen nicht verloren, „Die Bühne“ 1961; Worüber man in Polen lachte und lacht. Über die polnische Komödie, „Maske und Kothurn“, 1986.

72 Z mowy polskiej do obcej. Rozmowy z tłumaczami, rozm. W. Rutkiewicz, „Miesięcznik Literacki”, nr 2, 1971 (m.in. wypowiedź G. Leber-Hagenau), s. 41.

${ }_{73}$ M.in. Ponad różnicami kultur, rozm. W. Maciąg, ",Życie Literackie”, nr 42, 1975, s. 4.

${ }_{74} \mathrm{Z}$ rozmowy polskiej do obcej..., 41. 
w Polsce. Jak wielkie było moje rozczarowanie, gdy teatry niemieckojęzyczne - z Kolonii, z Wiednia z Burgtheater, z Zurichu - zwróciły mi manuskrypty i kierownicy literaccy pisali: «I z powodu tego dramatu Polacy prawie robili rewolucję?» Niezrozumienie totalne. Obcy świat dla nich. Pracowałam nad tym projektem także z Kazimierzem Dejmkiem, który zaczynał nawet już adaptację. Jednak w końcu zrezygnowaliśmy..."75.

Zainteresowanie polskim teatrem, dziejami adaptacji znanych utworów datuje się w wypadku Gerdy Leber-Hagenau jeszcze od czasów studiów teatrologicznych w Wiedniu pod kierunkiem wspomnianego Heinza Kindermanna. Jak pisze we wspomnieniach, „zbierałam materiały, nieraz nawet jeździłam specjalnie na jakieś ważniejsze premiery do Polski. Nigdy nie zapomnę przedstawienia w Teatrze Narodowym Historya o chwalebnym Zmartwychwstaniu Pańskim w adaptacji Kazimierza Dejmka. Natychmiast byłam zafascynowana tą jego inscenizacją. Byłam oszołomiona, w pauzie zaraz udałam się do dyrektora. Entuzjastycznie robiłam mu komplementy i prosiłam o zdjęcia z przedstawienia, aby natychmiast w Wiedniu o tej sensacyjnej inscenizacji napisać. «Jeszcze Polska nie zginęła» - zatytułowała redakcja moją entuzjastyczną recenzję. Wicedyrektor Anders powiedział mi, że ta moja recenzja była pierwszą z zagranicy i że ją chowają z wielką czcią $w$ archiwum teatru...

Nasz wiedeński Burgtheater zainteresował się też tymi inscenizacjami i posłał mnie do Warszawy na rozmowy na temat gościnnego występu Teatru Narodowego. Doszło do tego w roku 1968. Historya jak i Józef Reja były wielkimi sukcesami, i dla Teatru Narodowego i dla jego dyrektora Kazimierza Dejmka, który później jeszcze zrobił kilka inscenizacji w Burgtheatrze." ${ }^{76}$

Chociaż w późniejszym czasie Gerda Leber-Hagenau interesowała się głównie współczesną literatura, to jednak w jej dorobku można także odnaleźć nieco utworów z drugiej połowy XIX wieku i początków XX, jak np. opowiadania Bolesława Prusa, Władysława St. Reymonta, pamiętniki Mariana Rosco Bogdanowicza czy - jeszcze z lat wojennych - Warszawianka Stanisława Wyspiańskiego ${ }^{77}$.

Później przychodzi wieloletni okres zajmowania się współczesną literaturą polska, zarówno proza, jak i - przede wszystkim - utworami dramatycznymi.

Oprócz antologii „słowiańskich”, gdzie Gerda Leber-Hagenau zamieszczała także polskie opowiadania, jak np. w przypadku tomów

\footnotetext{
${ }^{75}$ G. Leber-Hagenau, Moi przyjaciele..., s. 10.

76 Ibidem, s. 21.

77 Por. Gerda Leber-Hagenau: Liste der Arbeiten über Polen (maszyn., stan 1990).
} 
Liebesgeschichten der slavischen Völker (1959) czy Moderne Erzähler slavischer Völker (1961), wiedeńska polonofilka opublikowała w 1961 roku głośną antologię Polen erzählt. 22 polnische Erzählungen (w większości we własnym przekładzie, obok takich uznanych tłumaczy, jak Walter Thiel, Henryk Bereska, Maryla Reifenberg, Armin Droß czy Kurt Harrer), uwzględniając m.in. takie nazwiska jak J. Iwaszkiewicz, T. Borowski, K. Filipowicz, A. Rudnicki. T. Nowakowski, B. Czeszko, K. Brandys, S. Dygat, S. Mrozek, R. Brandstaetter, Cz. Miłosz, M. Hłasko. W. Gombrowicz czy W. Odojewski.

Wspominając okres pracy nad antologią Polen erzählt, Gerda LeberHagenau pisze:

W roku 1961 ukazała się u S. Fischera we Frankfurcie moja antologia (...). Wtedy zaczął się okres mojego najżywszego kontaktu z teraźniejszą literaturą polską bo korespondowałam prawie ze wszystkimi autorami, przeczytałam ich opowiadania, wysortowałam, co mi się wydawało najlepsze i najciekawsze dla niemieckiego czytelnika i przedłożyłam do ostatniej decyzji wydawnictwu (...). (książka) ukazała się w trzech nakładach i osiągnęła 86.000 sprzedanych egzemplarzy. Ten malutki tomik miał wielki rezonans, przede wszystkim w Niemczech Zachodnich, gdzie studenci na uniwersytetach zaznajomili się po raz pierwszy z polską literatura, o której prawie nic nie wiedzieli ${ }^{78}$.

W dziedzinie polskiej prozy dużym przeżyciem było dla Gerdy Leber-Hagenau odkrycie fenomenu Włodzimierza Odojewskiego, którego przetłumaczyła Miejsca nawiedzone (1962), Wyspa ocalenia (1966) oraz Zasypie wszystko, zawieje (1977). W jej ocenie „Odojewski należy do tej klasy wielkich pisarzy, którzy idą swoją droga, którą uznali za odpowiednią dla siebie, czy mają na razie sukces czy też nie. Przez jakiś czas miał Odojewski wielki literacki sukces w Niemczech, przede wszystkim swoją powieścią Wyspa ocalenia, która się także ukazała w moim przekładzie u S. Fischera we Frankfurcie, i stąd poszła, tak jak Brandstaettera dramaty, dalej na cały świat (...). Widzę $\mathrm{w}$ nim jednego z najpotencjalniejszych pisarzy polskich do Nobla. Zobaczymy, czy mam rację, czy się myliłam" ${ }^{\prime 79}$.

Jednak najwięcej uwagi i twórczego wysiłku tłumaczka poświęciła bez wątpienia polskiej dramaturgii współczesnej, przyswajając językowi niemieckiemu m.in. utwory Romana Brandstaettera, Artura Marii Swinarskiego czy Ludwika Hieronima Morstina ${ }^{80}$.

W wypadku Romana Brandstaettera nie będzie przesada, jeśli się stwierdzi, że właśnie dzięki zabiegom Gerdy Leber-Hagenau stał się on

${ }^{78}$ G. Leber-Hagenau, Moi przyjaciele..., s. 19.

79 Ibidem, s. 18.

80 G. Leber-Hagenau, Wspótczesna literatura i teatr polski w Austrii [w:] Polacy w Austrii, Materiały..., red. A. Pilch, Kraków 1976. 
jednym z najbardziej popularnych autorów dramatycznych w Austrii, która przetłumaczyła kilka jego sztuk, np. Milczenie, Dzień gniewu czy Powrót syna marnotrawnego.

Roman Brandstaetter został także w swoisty sposób nobilitowany, jako że Dzień gniewu został m.in. wystawiony na pierwszej scenie wiedeńskiej - w Burgtheater, gdzie premiery swoje mieli bardzo nieliczni polscy autorzy. Karierę swoją rozpoczął Brandstaetter w roku 1960, kiedy to w znanym czasopiśmie literackim "Wort in der Zeit” ukazała się jego jednoaktówka Odys płaczacy, a na którego osnowie kompozytor Rudolf Bert skomponował muzykę i w postaci opery utwór ten został wkrótce wystawiony w Linzu.

O żywej reakcji publiczności wobec sztuk Brandstaettera świadczyły liczne inscenizacje w wielu teatrach; warto tutaj także przytoczyć relację Gerdy Leber-Hagenau z wieczoru poświęconego twórczości polskiego twórcy: „Rzadkie wzruszenie ogarnęło też publiczność na Matinee Brandstaettera w Akademietheater chyba w 1967 r., gdzie najlepsi aktorzy Burgtheater czytali jego poezję i jednoaktówkę Odys płaczacy. Odysa płaczacego czytał Fred Liewehr, poezję Albin Skoda, a Stabat Mater - wiersz o Matce Boskiej Treblińskiej z cyklu Pieśń o moim Chrystusie Hilda Wagner. Sama aktorka prawie nie mogła powstrzymać się od łez, a na widowni rozlegał się wielokrotnie szloch. Takie szczere wzruszenie w teatrze, to naprawdę bardzo rzadki przypadek" 81 .

W Austrii były tłumaczone nie tylko sztuki Brandstaettera, ukazały się również jego eseje i rozważania, jak m.in. Asyż był początkiem (1982) czy Z biblia w bagażu (1983).

Sukcesów odnosił Brandstaetter w Austrii wiele, niemal wszystkie zawdzięczał doskonałym przekładom Hagenau, jak miało to także miejsce w wypadku innych sztuk, np. Upadek kamiennego domu.

Wyrazem trwałego zainteresowania jego twórczością był fakt bardzo zaawansowanych prac Gerdy Leber-Hagenau nad przygotowaniem do druku wyboru trzynastu sztuk oraz tomu wierszy, które miały ukazać się w wiedeńskim wydawnictwie IRSA. Niestety nie doczekały się druku ${ }^{82}$.

Innym twórca, którego osobowość pozostała w żywej pamięci wiedeńskiej tłumaczki, był Ludwik Hieronim Morstin. W tłumaczeniu Hagenau ukazało się kilka jego sztuk nakładem kierowanej przez nią firmy Proscenium Edition. W swych wspomnieniach pisze m.in.:

... zjawił (się) Ludwik Hieronim Morstin, który dostał w Bregenz wyróżnienie za swoich Rycerzy Antychrysta. Zameldował się u mojego męża, który wtedy był dyrek-

\footnotetext{
81 Ibidem, s. 75.

${ }^{82}$ Gerda Leber-Hagenau, Liste der Arbeiten..., s. 10.
} 
torem wydawnictwa. Mój mąż, urodzony nad Renem w Niemczech, ale już długo żyjący w Austrii, nie rozumiał ani słowa po polsku, dlatego mnie prosił abym przyszła na rozmowę i tłumaczyła. I w tej pierwszej rozmowie Morstin spontanicznie mówił do mnie: «Niech Pani to przetłumaczy!» Chodziło o jego Penelopę, która miała większe szansę niż. Ja się broniłam mówiąc, że tego na pewno nie potrafię. «Potrafi Pani, potrafi!» wołał. No, i potrafiłam. 1 ze zdumieniem przekonałam się, że tłumaczenie z polskiego idzie mi bardzo łatwo. Niestety, dramaty Morstina nie trafiły do niemieckojęzycznych teatrów. Bardzo żałowałam, bo ceniłam i polubiłam tego autora bardzo, kawalera starej szkoły, typowo polskiego szlachcica (...) On i jego żona często u mnie gościli w Wiedniu, a jeszcze krótko przed jego śmiercią odwiedziłam go w jego mieszkaniu na Starym Mieście w Warszawie, na Krzywym Kole, jeśli się nie mylę blisko katedry św. Jana. Z dumą pokazywał mi oryginał portretu Marysieńki, pozującej jako Maria Magdalena. Dał mi wtedy też książkę Boya Żeleńskiego, abym się zainteresowała intensywniej Sobieskim, którego Listy do Marysieńki wtedy akurat ukazały się w Warszawie ${ }^{83}$.

Więzy serdecznej przyjaźni łączyły wiedeńską polonofilkę także z Arturem Marią Swinarskim, który ostatnie lata życia spędził w Wiedniu, pisząc w tym okresie swoje sztuki także w języku niemieckim.

Gerda Leber-Hagenau przetłumaczyła kilka jego dramatów, m.in. Achilles i panny czy Sasza i bogowie jeszcze z końcem lat pięćdziesiątych. Jak wspomina, „poznałam go, o ile dobrze pamiętam na przyjęciu w polskiej ambasadzie po występie gościnnym Starego Teatru z Krakowa w Wiedniu, chyba w 1954 r. Proponował mi wtedy, abym tłumaczyła jego dramaty. Przede wszystkim chodziło mu o Achillesa i panny, które wtedy były grane w Warszawie z wielkim sukcesem. Spełniłam życzenie autora, ale niestety sztuka wystawiona nie najlepiej na jakiejś małej scenie nie miała dużego sukcesu. Co nas tutaj powinno interesować to fakt, że świetny dramaturg polski Swinarski przez długie lata żył i pisał w Austrii, i że tam też, w wiedeńskim Rudolfspital, umarł w 1965 r. Ostatni okres życia Swinarskiego był pełen tragizmu. Pisał już tylko w języku niemieckim. W tym języku napisał kilka dramatów i jeszcze więcej fragmentów, szkiców. Sztuki te nie miały jednak powodzenia, nie były dotychczas wystawione ani raz. Wyobrażał sobie zapewne, jak wielu innych, że los emigranta jest łatwiejszy (...) Byłam tuż przed jego śmiercią przy nim w szpitalu. majaczył, miał jakieś wizje świata teatralnego. Może zainteresuje historyków literatury polskiej informacja, iż cały spadek literacki Swinarskiego znajduje się $\mathrm{w}$ moim posiadaniu. Wszystkie jego dramaty są $\mathrm{w}$ moim wydawnictwie teatralnym, oprócz tego mam duże archiwum z jego korespondencją, notatkami, fotografiami... ${ }^{84}$

Jak wiadomo, w międzyczasie Gerda Leber-Hagenau starała się jego prochy sprowadzić do Polski, jednak dotychczas plany te nie zostały

${ }^{83}$ G. Leber-Hagenau, Moi przyjaciele..., s. 12.

${ }^{84}$ G. Leber-Hagenau, Wspótczesna literatura..., s. 76. 
zrealizowane. Natomiast w swoim wiedeńskim mieszkaniu przechowywała jego całe archiwum literackie.

Zainteresowania polską dramaturgią współczesną to także tłumaczenie sztuk J. Zawieyskiego, B. Jasieńskiego czy S. I. Witkiewicza, które to Gerda Leber-Hagenau publikuje najczęściej w swym wydawnictwie teatralnym Proscenium Edition, zasłużonym dla sprawy promocji polskiej sztuki współczesnej.

Jakkolwiek wiedeńska tłumaczka zajmuje się głównie literaturą piękna, to jednak w jej dorobku można odnaleźć także przykłady innych jeszcze pozycji, jak np. Kardynała Stefana Wyszyńskiego Der Christ und die Arbeit (1959).

W swej misji polonofilskiej Gerda Leber-Hagenau nie ograniczała się do samych tylko przekładów. Spod jej pióra - prócz wspomnianych wcześniej licznych artykułów i szkiców rozsianych na łamach prasy - wyszła też pewna ilość pozycji historycznych, z których na czoło wysuwa się obszerna książka Jan Sobieski, der Retter Wiens, opublikowana w roku Odsieczy Wiedeńskiej 1983, stanowiąc jeden z głównych akcentów tej ważnej rocznicy, uroczyście obchodzonej nad Dunajem. Na bazie licznych archiwalnych dokumentów i dotychczasowej literatury przedmiotu, Gerda Leber-Hagenau stworzyła interesujący konterfekt króla, skupiając się na naszkicowaniu jego sylwetki psychicznej. W jednym z wywiadów, powstałych jeszcze przed ukończeniem książki, autorka powiedziała: „Wiedeńskie wydawnictwo prosiło mnie o napisanie książki o Janie Sobieskim. Zgodziłam się. Zaczęłam się tą postacią interesować bliżej i... nie mogłam przestać. Piszę biografię Sobieskiego, ale interesuje on mnie bardziej jako człowiek, a niejako król czy hetman (...) lubił życie szlacheckie, przyjaciół. Był jednocześnie bardzo ambitnym, wybuchowym, honorowym i... sentymentalnym" ${ }^{\prime 2}$.

W 1994 roku ukazał się obszerny tom I (i niestety ostatni) szeroko zaplanowanej pracy pt. Polnisches Theater und Drama, przynoszący barwną panoramę polskiego teatru od początków do 1795 roku. Gerda Leber-Hagenau ukazała nie tylko dzieje teatralne, ale szeroko rozumianą kulturę teatralną i rozwój polskiego dramatu do końca Niepodległości.

W 1999 roku wiedeńska uczona i tłumaczka opublikowała studium Adam Mickiewicz als Dramatiker, będące wnikliwą analizą dramatycznej twórczości autora. Tekst historyczno-literacki został wzbogacony tłumaczeniem Dziadów, doskonale ilustrującym wywody z pierwszej części książki.

85 O Sobieskim i Polonii... (m.in. wypowiedź G. Leber-Hagenau), Polonijne Spotkania Pokoleń, lipiec 1983, s. 10. 
W dwa lata później ukazał się zbiór wcześniej publikowanych rozpraw i szkiców Gerdy Leber-Hagenau z zakresu literatury polskiej i niemiecko-polskich stosunków kulturalnych pt. Zwischen deutscher und polnischer Literatur (2001).

Książki wiedeńskiej uczonej, zwłaszcza wydane $\mathrm{w}$ latach dziewięćdziesiątych, stawiają Gerdę Leber-Hagenau w rzędzie zasłużonych slawistek austriackich, zwłaszcza w zakresie polskiego dramatu i teatru.

Kolejnym nurtem działalności Gerdy Leber-Hagenau było jej własne, oryginalne pisarstwo, w którym wątek polonofilski zajmował ważną pozycję, np. w wypadku jej obszernej powieści Lucyna Herz (1958) czy całego szeregu drobniejszych pozycji, jak opowiadania Das anbetende Pferd, Profesor Jaworski czy Im Inter-City.

Szczególnym uznaniem cieszy się Lucyna Herz, do której to powieści zaczerpnęła pomysł z wiersza Stanisława Jerzego Leca, i w której opowiada losy znanej dziewczyny - partyzantki, działającej podczas okupacji hitlerowskiej w Polsce.

W 1998 roku ukazało się w Warszawie dwujęzyczne wydanie elegii Gerdy Leber-Hagenau Chwalcie ten świat. We wstępie do tomiku napisał Bonifacy Miązek m.in. „Forma elegijna tych utworów, gdzie wspomnienia, melancholia, smutek i rezygnacja przystają w filozoficznych pytaniach nad heraklitowską rzeka, oddaje najpełniej koloryt czasu, w jakim one powstały".

Wiele swoich pomysłów artystycznych w postaci tłumaczeń polskich autorów (we własnym przekładzie lub innych translatorów), czy prac na temat literatury polskiej, Gerda Leber-Hagenau była w stanie realizować dzięki prowadzeniu firmy wydawniczej: wspomnianego już kilkakrotnie Proscenium Edition/Gerda Leber-Verlag, w którym to ukazała się m.in. głośna praca Bonifacego Miązka Polnische Literatur 1863-1914 w 1984 roku, czy - nieco wcześniej - homilie Jana Pawła II oraz wspomnienia Fr. J. Młodożeńca o Maksymilianie Kolbe.

Nie sposób nie wspomnieć też o szerokiej, prowadzonej przez lata przez Gerdę Leber-Hagenau akcji odczytowej. Szczególne jej nasilenie nastąpiło z okazji rocznicy 300-lecia Odsieczy Wiedeńskiej, kiedy to Hagenau, jako autorka książki o Janie III Sobieskim, wielokrotnie występowała przed licznie zebraną publicznością, by przykładowo wspomnieć o jej odczytach wygłoszonych w Nowym Jorku, czy w wiedeńskim Instytucie Polskim lub w Club des Verbandes der Akademikerinnen Österreichs.

Gerda Leber-Hagenau działała także przez wiele lat w kilku towarzystwach, jak Towarzystwo Austriacko-Polskie, Międzynarodowy Komitet Chopinowski. Zasiadała także jako członek redakcji czasopisma „Österreich-Polen”, bywała zapraszana do prestiżowych gremiów, jak 
m.in. Komitet Honorowy 300-lecia Odsieczy Wiedeńskiej.

Całokształt działalności polonofilskiej Gerdy Leber-Hagenau był niezwykle bogaty i różnorodny. Przez niemal pół wieku działała ona owocnie dla dobra rozpowszechniania kultury polskiej w świecie, dając przykład zaangażowania oraz sprawnego warsztatu polonistycznego i translatorskiego. Dysponowała ogromnym zapasem energii, np. świadczy o tym fakt wieloletniej pracy nad jednym z największych dzieł jej życia: dziejami dramatu i teatru polskiego. A więc tematem, który fascynował ją przez wiele dziesięcioleci. Przed laty Gerda Leber-Hagenau powiedziała: „...najlepsza nawet proza nie może poskromić we mnie temperamentu teatralnego. Teatr to mój wieloletni $\langle$ konik $\rangle$, bo od dawna przecież pracuję nad historią dramatu polskiego. Zebrałam mnóstwo często wręcz unikalnych materiałów..." ${ }^{\prime 86}$.

Fascynacja polskim teatrem, latami zbierane materiały na temat polskiej sceny dawnej i współczesnej, skłoniły Gerdę Leber-Hagenau do podjęcia się opracowania o charakterze monograficznym - o czym było powyżej. W jednym z wywiadów mówiła o tym następująco:

Tom pierwszy już w zasadzie ukończyłam. Pozostały mi jeszcze przypisy i ogólna kosmetyka stylistyczna. Obejmuje on okres od roku 1025 do 1795, czyli do III rozbioru Polski. Wydam go prawdopodobnie w jednej z oficyn niemieckich. Natomiast tom drugi, który zawierać będzie materiały od roku 1795 do współczesności, ukaże się nie wcześniej niż za 2-3 lata. Pomiędzy tymi tomami chciałabym bowiem opracować moje pamiętniki...87.

Była to wypowiedź z początku roku 1992, natomiast w kilka miesięcy później Gerda Leber-Hagenau - pod wrażeniem uczestniczenia w Światowym Spotkaniu Łodzian - zafascynowana ponownym spotkaniem ze swym rodzinnym miastem, postanawia podjąć pracę nad wspomnieniami o Łodzi, rezygnując jednocześnie z planowanego II tomu z zakresu historii polskiego teatru.

W liście z dnia 11 stycznia 1993 roku pisała:

Jak prędko ten czas leci! W wywiadzie mówiłam jeszcze o II tomie mojej historii teatru polskiego. A tu się wszystko zmieniło. 1 tom skończyłam przed świętami, teraz potrzebna tylko jeszcze przedmowa i Nachwort, no i wszystkie te rzeczy jak register,

${ }^{86}$ Z mowy polskiej do obcej..., s. 42. Por. także: Zaproszenie do Wiednia, rozm. K. Zdrojewski, "Odgłosy”, nr 44, 1978, s. 8; E. Rosner, Literatura polska w Austrii. Z problemów recepcji po 1945 r., „Przegląd Zachodni”, nr 3, 1989; tenże, Zarażona Polską..., "Hejnał Mariacki”, nr 4,1988; tenże, Roman Brandstaetter w Austrii [w:] Z tej ziemi, „Śląski kalendarz katolicki na rok 1990”, Katowice 1989.

${ }^{87}$ Między literaturą a teatrem. Rozmowa z prof. Gerdą Leber-Hagenau, pisarka, tłumaczką literatury polskiej i historykiem, rozm. K. A. Kuczyński, „Kronika. Pismo Uniwersytetu Łódzkiego", nr 6 (13), 1992, s. 12. 
fotografie etc. etc. I jakoś zdecydowałam się, jeszcze jeden rozdział napisać, mianowicie o romantyzmie, i na tym skończyć, drugiego tomu już nie napisać. Tytuł ma brzmieć: Polnisches Theater und Drama. Ein integraler Bestandteil europäischer Theaterkultur. Von der Romanik bis zur Romantik.

Niech się już ktoś inny męczy z drugim tomem. Ja zapaliłam się - nie zgadnie Pan, do czego! - jednak do mojej powieści o Łodzi, tak długo planowanej, Am Webstuhl der Zeit.

We wrześniu byłam na światowym spotkaniu Łodzian, były też wywiady ze mną $\mathrm{w}$ radio i w gazetach, no i doszło do tego, że potem zostałam zaproszona do współpracy nad filmem o Łodzi, dokumentalnym, ale ma to być niby kontynuacja trzech bohaterów z Ziemi obiecanej Reymonta. I już zaczęła pracować moja głowa i moja fantazja. Może połączę te losy w mojej powieści z losami mojej rodziny..." ${ }^{88}$.

Integralną część ukończonego w 2000 roku autobiograficznego utworu o Łodzi pod roboczym tytułem Villa Krause ${ }^{89}$ stanowią lata międzywojenne, gdyż ten okres Gerda Leber-Hagenau pamiętała szczególnie dokładnie. W cytowanym wywiadzie wspominała, iż przechowuje „do dzisiaj wiele zeszytów moich pamiętników z tamtych czasów. Myślę, że będzie to ciekawe. Dobrze też pamiętam Łódź okresu międzywojennego. Mój ojciec był znanym przemysłowcem, miałam też rodzinę w okolicach Łodzi. To czasy, które powoli odchodzą w przeszłość; sądzę, że warto je utrwalić dla naszych dzieci i wnuków, które znają to wszystko bardzo powierzchownie, fragmentarycznie" ${ }^{\prime 90}$.

Warto nadmienić, że w 1990 roku Gerda Leber-Hagenau opublikowała interesujący reportaż - przeplatany wspomnieniami z lat młodości - ze swojej wizyty w Łodzi w 1978 roku, przybywając do Polski jako gość Polskiej Akademii Nauk. Jest on jednocześnie wartościowym przyczynkiem do naszej wiedzy o dziejach mniejszości niemieckiej w okręgu łódzkim ${ }^{91}$.

Twórczość Gerdy Leber-Hagenau, zarówno translatorska, jak również oryginalna, czy to w postaci wierszy, powieści, opowiadań i reportaży, czy prac krytycznoliterackich bądź historycznych, pozwala upatrywać w nich ważkich dokumentów atrakcyjności kultury polskiej, interesujących dla niemieckojęzycznego czytelnika.

W ostatnich latach życia dużo radości sprawiała jej coraz większa popularność, m.in. film „Profesor Gerda” (1994).

Ukoronowaniem i podsumowaniem wieloletniej działalności pisar-

88 Por. List G. Leber-Hagenau do K.A. Kuczyńskiego z dn. 11.1.1993.

89 Pozycja ta nie została niestety do dzisiaj opublikowana

90 Między literatura a teatrem..., s. 12.

${ }^{1}$ G. Leber-Hagenau, Bunte Scherben [w:] Wo wir einst zu Hause waren... Gespräche und Begegnungen mit einem anderen Land, hrsg. von Peter Nasarski, Berlin-Bonn 1990, s. 97-109; Por. także: E. Rosner, Szkic do portretu Gerdy Leber-Hagenau, „Ruch Literacki“" nr 1-2, 1992, s. 73-89. 
skiej i tłumaczeniowej wiedeńskiej polonofilki było zorganizowane w Łodzi w 1997 roku - w przededniu 80. rocznicy urodzin - międzynarodowe sympozjum pt. "Gerda Leber-Hagenau a stosunki polsko-austriackie w XX wieku" z udziałem wielu prominentnych gości z Austrii, Niemiec i Polski ${ }^{92}$.

Gerda Leber-Hagenau zmarła 8 sierpnia 2004 roku w Zell am Moos k. Salzburga nad jeziorem Irrsee, gdzie od lat kilkudziesięciu zwykła była spędzać letnie miesiące.

\section{III}

W okresie powojennym literatura polska jest obecna w Wiedniu m.in. dzięki tłumaczom, którzy niemieckojęzycznemu odbiorcy udostępnili liczne pozycje, głównie z zakresu piśmiennictwa współczesnego. Jest to zasługa cenionych polonofilów, mających na swym koncie także własne utwory oryginalne, nawiązujące nierzadko do tematyki polskiej ${ }^{93}$.

O ile jednak tworzyli oni swoje dzieła przeważnie $w$ języku niemieckim, co było logiczną konsekwencją ich osadzenia w kulturze i języku miejsca zamieszkania i są słusznie uważani za pisarzy austriackich, to można także wyróżnić inną, chociaż niezbyt liczną grupę twórców z Polski, którzy przebywali wprawdzie przez pewien czas nad Dunajem, jednak nie pretendowali $\mathrm{z}$ natury rzeczy do zaszeregowania ich $\mathrm{w}$ poczet pisarzy miejscowych, austriackich, jako że pisali głównie po polsku, a i większość z nich wróciła z czasem do kraju. Byli to m.in. Aleksander Jackiewicz, Stanisław Jerzy Lec czy Artur Maria Swinarski ${ }^{94}$.

W tej ciekawej mozaice polskich oraz austriacko-polskich twórców można szczególnie wyróżnić casus Bonifacego Miązka, mieszkającego od kilkudziesięciu lat w Austrii, poetę i slawistę, piszącego swoje interesujące wiersze wyłącznie po polsku ${ }^{95}$.

${ }_{92}$ Por.: Gerda Leber-Hagenau a stosunki polsko-austriackie w XX wieku, pod red. K.A. Kuczyńskiego i D. Kucharskiej, Toruń-Płock 1998.

${ }_{93}$ Por. m.in.: Gerda Leber-Hagenau a stosunki polsko-austriackie...; E. Rosner, Znad Wisły i Dunaju. Szkice o polsko-austriackich powiązaniach literackich, Cieszyn 1998; Polska-Austria. Drogi porozumienia, pod red. K.A. Kuczyńskiego, A. Kozłowskiego, B. Miązka, Łódź 1999.

${ }_{94}$ Por.: A. Kozłowski, K.A. Kuczyński, Polskie fale Dunaju. Polsko-austriackie powinowactwa kulturalne, Częstochowa 1992.

95 Por. m.in.: Szkice do portretu Bonifacego Miązka, pod red. J. Pacławskiego, Kielce 2000; K.A. Kuczyński, Ze wsi w daleki świat. O życiu i twórczości ks. prof. Bonifacego Miązka, Łódź 2007; Powrót do domu. Księdzu Infułatowi prof. dr hab. Bonifacemu Miązkowi w 75. rocznicę urodzin. Księga Jubileuszowa, pod red. H. Kołodziejczyka, K.A. Kuczyńskiego i P. Obrączki, Łódź 2010; J. Radłowska, Dwie emigracje. Bonifacy Mią- 
Swoistym fenomenem jest także postać Adama Zielińskiego, autora debiutującego późno, bo dopiero w wieku lat 60. Wcześniejsze lata wypełniła mu wytężona praca zawodowa $\mathrm{w}$ zakresie handlu i ekonomii, w których to dziedzinach doszedł do godnych uwagi osiągnięć. Na wzięcie pióra do ręki zdecydował się w końcu lat 80 ., wtedy to ukazały się jego pierwsze utwory, z czasem coraz liczniejsze powieści i opowiadania, publikowane zarówno w języku niemieckim, jak i polskim, zdobywając sobie w Austrii i w Polsce uważnych i życzliwych czytelników ${ }^{96}$.

$* * *$

Adam Zieliński urodził się 22 czerwca 1929 r. w galicyjskim Drohobyczu, mieszkając następnie z rodziną w Stryju oraz we Lwowie (lata 1941-1945). Po wojnie i przymusowym opuszczeniu swojej „małej ojczyzny" osiadł w Krakowie. O Galicji nie zapomniał nigdy, wiele lat później, w 1997 r. w Galicyjskim prowincjuszu napisał m.in.: „Ojczyzny się nie wybiera. Ojczyzna wdziera się sama do ludzkiej głowy i duszy przez jakiś niewidoczny, ale za to prawdziwie czarodziejski lejek. Jakże często zdarza się, że ludzie wypędzą człowieka z jego ojczyzny, bezlitośnie obija może nawet zabiją najbliższych. To wszystko nie zdoła wymazać z pamięci tych, którzy jeszcze żyja galicyjskich zapachów, wspomnień, obrazów, dźwięków, kolorów, wzruszeń, radości, rozpaczy, uniesień, iluzji, miłości, rozczarowań... Wszystkiego, czym ojczyzna potrafi obdarzyć. Zapach Galicji towarzyszy mi dziś z taką samą intensywnością z jaką poczułem go po raz pierwszy przed wielu, wielu, bardzo wielu laty"97.

W Krakowie ukończył Adam Zieliński szkołą średnia, by następnie w 1946 r. podjąć studia na Wydziale Filozoficzno-Społecznym Uniwersytetu Jagiellońskiego, a później w Warszawie na Wydziale Dziennikarstwa tamtejszego uniwersytetu. W 1956 r. otrzymał tytuł magistra.

Studia dziennikarskie spowodowały, że Adam Zieliński podjął swoją pierwszą pracą zawodową w charakterze dziennikarza w Rozgłośni Polskiego Radia w Krakowie. Jednak warunki polityczno-społeczne w kraju, ucisk ideologiczny spowodowały, że już wkrótce, w połowie 1957 r., decyduje się na emigracją do Austrii.

zek - poeta, krytyk i historyk literatury, Wrocław 2012.

${ }^{96} \mathrm{~W}$ jednej książek A. Zielińskiego, Galicyjski prowincjusz. Ein Provinzler (Kraków-Wiedeń 1997) odnajdujemy bibliografię przedmiotowa, a więc wykaz recenzji książek Adama Zielińskiego oraz artykułów poświęconych jego życiu i twórczości w opracowaniu Tadeusza Skoczka. Zestawienie to ukazuje duże zainteresowanie powieściami i nowelistyką wiedeńskiego autora.

97 A. Zieliński, Galicyjski prowincjusz. Ein Provinzler, Kraków-Wiedeń 1997, s. 25-26. 
Nie była to decyzja łatwa choćby z uwagi na nieznajomość języków obcych, a więc także i niemieckiego. Jednak niechęć do wszelkiego rodzaju totalitaryzmu i pragnienie życia z rodziną w wolnym kraju były silniejsze od tego rodzaju obaw. I rzeczywiście, pierwsze lata pobytu w Austrii były niezwykle trudne. Jak pisze sam Adam Zieliński, „brak znajomości języka daje uczucie zupełnej obcości. Emigracja oznacza przede wszystkim pokonanie owej bariery, która oddziela człowieka od całego ,nowego świata', od telewizji, od rozmowy z sąsiadami, ze sklepikarzem. Nieznajomość obcego języka używanego w państwie, dokąd się emigruje, to jedno z najbardziej gorzkich uczuć, jakie może doznać człowiek ${ }^{98}$.

Od roku 1962, kiedy to zakłada własną firmę handlowa, rozpoczyna Adam Zieliński mozolny marsz w górę drabiny społecznej. Po latach pracy, gdy zdobył własnym wysiłkiem, energią i przedsiębiorczością status wybitnego eksperta ekonomicznego oraz wysoką stabilizację życiowa, pomyślał u schyłku lat 80. o urozmaiceniu swoich zainteresowań i wykorzystaniu doświadczeń zdobytych zarówno w Austrii, jak i podczas licznych podróży po świecie, zwłaszcza do Chin, w których był ponad sto razy i które urzekły go nie tylko odmiennością kultury, ale i specyficznym stosunkiem do problemów otaczających współczesnego człowieka.

Adam Zieliński zapragnął przelać na papier rozliczne własne wątpliwości i rozterki, a także raz jeszcze - tym razem w postaci fikcji literackiej (chociaż z niewątpliwymi odniesieniami do rzeczywiście istniejących i działających nie gdyś lub obecnie osób) zmierzyć się z wieloma problemami i pytaniami nurtującymi człowieka w kończącym się XX stuleciu; wspaniałym, ale i strasznym jednocześnie, już choćby z uwagi na ogromny potencjał nagromadzonej nienawiści, znajdującej ujście w światowych wojnach i licznych, nie mniej krwawych, lokalnych spięciach.

Niewątpliwie wiedział, że potrafi analizować, a także portretować gorzkie czasem obrazy i przeżycia. A nazbierało się ich sporo w jego jakże ciekawym, ale niełatwym życiu emigranta.

Przygotowanie do podjęcia tego z czasem wielotomowego dyskursu z szalonym i okrutnym ,garbatym światem', do poddania się pisarskiej pasji posiadał niezłe: w 1982 r. uzyskuje stopień doktora w zakresie nauk politycznych na jednym z amerykańskich uniwersytetów. Bez przerwy jeździ po świecie, rozmawia z ciekawymi ludźmi, wiele czyta i obserwuje. I ciągle jeszcze czynny zawodowo: jest doradcą ekonomicznym rządu austriackiego z tytułem Kommerzialrat, jest wielokrotnie odznaczany w Austrii, Polsce i kilku innych krajach. Został np. uhonorowany nad Dunajem Złotym Krzyżem Zasługi, Orderem Wielkiej Gwiazdy Wiednia,

98 T. Kraśko, Z Adamem Zielińskim wiedeńskie rozmowy, Kraków 1995, s. 12. 
a także decyzją prezydenta otrzymał godność profesora. Z kolei ze strony polskiej uzyskał Krzyż Komandorski Orderu Polonia Restituta, akademickie odznaczenie Uniwersytetu Jagiellońskiego „Merentibus” a także inne nagrody, jak warszawskiego pisma „Literatura” czy Nagrodę im. Jana Adamczewskiego.

Z ramienia Stacji Naukowej Polskiej Akademii Nauk w Wiedniu zostało w 1999 r. zorganizowane sympozjum poświęcone jego twórczości literackiej. Nagród i odznaczeń innych krajów zebrało się sporo, wymienić by tutaj można m.in. paryską nagrodę „Lutecja 98”, przyznaną przez Kapitułę Europejskich Nagród Honorowych czy Order Jugosłowiańskiej Flagi na Szerokiej Wstędze z Gwiazdą.

$$
* \quad * \quad *
$$

Jakkolwiek początków literackiej kariery Adama Zielińskiego należy szukać w końcu lat 80., kiedy to w języku niemieckim ukazała się saga rodzinna Die Zielińskis, opublikowana w Gerda-Leber-Verlag w Wiedniu, to jednak nie jest wykluczone, że swoistego bakcyla kontaktu z publicznością - mimo, że nastąpiło to przed wielu laty w innym kraju i za pomocą innych środków - połknął wiedeński twórca jeszcze jako dziennikarz Polskiego Radia w Krakowie, kiedy przygotowywał teksty, aby następnie wysłać je w eter, tak jak to obecnie czyni wydając książki, aby spoczęły w rękach niemieckojęzycznego i polskiego (a także sporadycznie i anglojęzycznego) odbiorcy.

Można się zgodzić z twierdzeniem, zwłaszcza po lekturze nie tylko powieści i opowiadań, ale i trzech tomów z rozmowami z Adamem Zielińskim (w opracowaniu Tadeusza Kraśko oraz Leszka Żulińskiego), że wiedeński twórca poczuł z czasem niepowtarzalny smak literackiej przygody. Urok, ale i niezmierny wysiłek intelektualny zafascynował go. Tym bardziej, że zapragnął pokazać, iż „człowiek z końca XX wieku jest istotą rozdarta, zagubiona, $\mathrm{z}$ najwyższym trudem walczącą o swój sens życia, o swoją godność, miejsce na coraz bardziej zatłoczonej - i zarazem jakby coraz bardziej pustej - ziemi" ${ }^{\prime \prime 9}$.

Pierwsze książki Adama Zielińskiego to jednoznacznie utwory polityczne, rozrachunkowe. To rozliczenie się, być może z własnych trudnych czasów krakowskich i warszawskich, kiedy to doznał bezpośrednio ludzkiej nienawiści i podłości. To nie dążność do opisania tamtych zniewolonych lat tylko dlatego, aby dać upust nagromadzonemu z pewnością żalu. Jest to $\mathrm{w}$ pierwszym rzędzie literacki, artystyczny zamiar analizy zachowań i postaw ludzi, którzy ulegli złudzeniu, iż w ówczesnym syste-

99 Ibidem, s. 26. 
mie ich nijakie, marne osobowości urosły nagle do znaczących wymiarów, dających jakoby prawo do uczestniczenia we współkształtowaniu wycinków rzeczywistości, czy choćby losów innych, a więc w nikłym wymiarze i małym znaczeniu wobec decyzji globalnych, ale jakże nikczemnych i przykrych dla jednostek wydanych na łup tego rodzaju osobników.

Z czasem horyzont artystycznych dokonań Adama Zielińskiego znacznie się rozszerza, po Garbatym świecie z 1993 r. ukazują się kolejne książki: Niedaleko Wiednia (1993) oraz Cichy Dunaj (1994). To także powieści polityczne, ale o znacznie poszerzonej wymowie społecznej. Bałkany, w tym przypadku obszar byłej Jugosławii, jest w dużym stopniu tematem pasjonującym pisarza. Cały szereg indywidualnych losów składa się na tragedię tych ziem, ludzi, którzy zmuszeni są opuścić swój kraj, szukając schronienia także w Austrii. Ich pobyt nad Dunajem, jakże celnie uchwycony przez Adama Zielińskiego, należy do mocnych stron Niedaleko Wiednia. Podobnie jak odzew tych spraw w dalekiej Ameryce, w Bostonie. Trudno tam zrozumieć złożone problemy kraju w Europie. Pod piórem Zielińskiego widać, jak zmienia się wymiar tragedii ludzi, ich ojczyzny zależnie od ilości kilometrów, inności poglądów, religii czy wreszcie wrażliwości sumienia. Jak rozmyśla jeden z bohaterów książki nad losami narodów bałkańskich, „każdy, zawieszony między opozycyjnymi biegunami, co jakiś czas bywa rozszarpywany przez rozjuszonego, wczorajszego sąsiada, a wykrwawiwszy się do imentu pada gdzieś jak cuchnące ścierwo szakala. Czyż historia Bałkanów nie jest historią nieustannych intryg, spisków i wzajemnych podjudzeń? Czy nie jest historią podżeganie do nienawiści, niezliczonych zamachów i bezceremonialnych uwięzień? Ale tak to zwykle bywa z małymi narodami, które zmuszone są dzielić niewielką przestrzeń, zaczęło się to już w raju..." ${ }^{100}$.

Skomplikowane ludzkie losy, niespodziewane sytuacje i jakże trudne obrazy dla ich literackiego uchwycenia, to odczucia towarzyszące lekturze Cichego Dunaju, którego kanwą - choć nie tylko - są dzieje austriackiego obozu dla uchodźców z wielu państw świata, którzy swój życiowy przystanek, na dłużej lub na krócej, znaleźli właśnie w Wiedniu. Konflikty etniczne, religijne, zwykle ludzkie słabości urastają nierzadko do wymiarów przerastających ich możliwości wytrwania. Toteż często przychodzi czytelnikowi widzieć ludzkie upadki, nieszczęścia i tragedie. To codzienni niemal towarzysze ludzi bez ojczyzny...

A jak przyjmują wiedeńczycy coraz nowe fale przybyszów z wielu krajów? Na kartach powieści można odnaleźć i taki pogląd: „Gdyby wszystkie te narody, które zwykle stoją na najniższym szczeblu światowej hierarchii, nadal pozostały tak bardzo ubogie, a my utrzymamy nasz

100 A. Zieliński, Niedaleko Wiednia, Warszawa-Kraków-Wiedeń 1993, s. 163. 
wysoki poziom życiowy, wówczas dojdzie do ogromnych przemieszczeń demograficznych! A co nastąpi potem? Potem przyjdzie wojna! Oni, te dzikusy, będą naturalnie mówili o sprawiedliwej wojnie, a może i będą mieli rację po swojej stronie. Ta przeklęta kula ziemska staje się zbyt mała. Biedni sięgną prędzej czy później po majątek bogatszych"101.

Ludzkie losy, ich zmienność, niespodziewane wzloty i upadki, to w wielkim skrócie temat panoramicznej powieści Powrót, której akcja rozciąga się na olbrzymim obszarze nie tyko w sensie geograficznym, ale i czasowym. W latach 1937-1996 Adam Zieliński zawarł niezwykle różne sytuacje, od rodzinnej ziemi galicyjskiej, poprzez zsyłkę na Sybir, ponownie do Europy, do Austrii. Nie tylko tej współczesnej, ale i tej ponurej, czasów III Rzeszy...

Rodzina Władysława Bałtyckiego, tragicznie doświadczona w minionych latach, $\mathrm{w}$ wiele lat po wojnie spotyka się $\mathrm{u}$ jego grobu w Stryju. Minione czasy poczyniły duże wyrwy w ich szeregu, czasy obfitujące w tragedie, rozpacz i śmierć. Jego dzieci nad mogiłą stały „.obok siebie, ich dłonie splotły się. Wszystko, co przeszli - dzieciństwo, młodość, lata dojrzałe, osamotnienie, osiągnięcia, szaleństwa i sukcesy, obce kraje, Sokół i starosta Kolbuszewski, wielce szanowna i czcigodna pani, a także burze śnieżne nad rzeką Ob - wszystko to, co było ich przeszłością przesunęło się błyskawicznie jak film przed ich oczami. Czego jeszcze mogli oczekiwać od przyszłości? Już niewiele"102.

Swoista brutalizacja wcześniejszych obrazów, ich konieczny naturalizm spowodowany atmosferą czasów, ich władców prawdziwych i pozornych, ustępuje miejsca zadumie, jakże typowej dla pisarstwa Adama Zielińskiego. Ludzkie portrety, przejmujące poprzez duży ładunek autentycznych - lub zbliżonych do autentycznych - sytuacji, układają się w łańcuszek panoramy naszych czasów. Ich różnorodność, zindywidualizowanie i „pełnokrwistość” zagadnień czyni z nich literaturę nadzwyczaj interesująca, ale także zdumiewającą odpowiedzialnością za słowo. Słowo pisarza, który tworzy swój utwór w posłannictwie, aby zachować dla potomności prawdę, czasem straszną.

Rzadko który pisarz nie powraca w swej twórczości do krainy dzieciństwa i młodości. Toteż było tylko kwestią czasu, kiedy Adam Zieliński podejmie temat Galicji w szerszym zakresie. I rzeczywiście, jego ostatnie pozycje nawiązują do ziemi galicyjskiej, do miejsca urodzenia. Już same tytuły świadczą o chęci nawiązania kontaktu z dawno minionym czasem, jak choćby Galicyjski prowincjusz z roku 1997, czy wydane rok później

101 A. Zieliński, Cichy Dunaj, Warszawa 1994, s. 42-43.

102 A. Zieliński, Powrót, Kraków 1996, s. 268. 
opowiadanie Hołobutów. Swoją ziemię rodzinną podziwiał Adam Zieliński jeszcze jako chłopiec, sam o tym mówił następują co: „W czasie mojej młodości (...) zachwycałem się, co dzisiaj jest wśród młodzieży na ogół niecodzienne, naturą. Lasy w tym szczęśliwym czasie były jeszcze zdrowymi lasami, pełnymi zwierzyny, w każdym razie całe południe mojej lwowskiej ojczyzny tak właśnie wyglądało. Zachwycałem się tą ziemia, jej tradycjami, folklorem. Paliliśmy jako młodzi harcerze ogniska, wokół których opowiadaliśmy sobie baśnie, legendy, śpiewaliśmy smutne, ale i skoczne piosenki. Odnoszę wrażenie, że łatwiejsze było wtedy porozumiewanie się między ludźmi, a być może także między innymi stworzeniami i naturą..."103.

Sentyment do rodzinnych stron jest zrozumiały, pojawia się mimo woli pytanie, jak połączyć to uczucie z faktem, że od $1957 \mathrm{r}$. nie mieszka Adam Zieliński w Polsce, zaś jeszcze wcześniej, bo od 1945 r. nie mieszka - co prawda nie ze swojego wyboru - w Galicji? Odpowiedź nie jest łatwa, choć znając losy rodziny Adama Zielińskiego, jego emigrację nad Dunaj i znalezienie swojego miejsca w Austrii, można spodziewać się odpowiedzi. Wydaje się więc, że autor Galicyjskiego prowincjusza trafia we właściwą strunę, gdy powiada: „Jestem Galicjaninem i nigdy nie przestanę nim być. Zrozumiałem to, kiedy przemyślałem moje podróże do Tokio i Nowego Jorku, do Madrytu i Johanesburga, do Helsinek i do Caracas. W moich snach nie ma wspomnień z tych wielkich, wspaniałych, sławnych miast, za to pełno nieokiełznanego wiatru, nadciaggającego od krainy mojego dzieciństwa. Pełno w tych snach pszenicznych pól, złotych jak słońce. Kłaniają się nisko stepowemu wiatrowi..."104.

Może ktoś powiedzieć, że te piękne słowa, pełne poezji i miłości do rodzinnej, dalekiej ziemi, to literacka fikcja, zdania włożone w usta bohatera opowiadania, owego galicyjskiego prowincjusza. Ale oto w jednej z bezpośrednich wypowiedzi Adama Zielińskiego odnajdujemy ten sam motyw, jeszcze wyrażony bardziej bezpośrednio: „Kocham miejsce mojego urodzenia, kocham miejsce, gdzie uczyłem się mówić, czytać i pisać, kocham miejsce, gdzie po raz pierwszy spotykałem się z dziewczyną ale z całą przyjemnością odwiedzam na przykład wodospad Niagara lub zbocza Fudżijamy. Nigdy w życiu nie wypoczywałem tak dobrze, jak w Indonezji, na wyspie Bali, i przypuszczam, że gdyby ktoś zaproponował mi kilkuletni pobyt, zastanawiałbym się, czy takiej propozycji nie przyjąć (...) ojczyzna to największy skarb, do ojczyzny się wraca, aby naładować baterie, aby zadowolić serce, aby znowu odczuć słodycz miejsca, w którym się

103 T. Kraśko, Z Adamem Zielińskim wiedeńskie rozmowy, Kraków 1995, s. 94-95.

104 A. Zieliński, Galicyjski prowincjusz. Ein Provinzler, Kraków-Wiedeń 1997. s. 2425. 
urodziło, ale wcale nie oznacza to w nowoczesnym świecie, że ojczyzna to miejsce, gdzie koniecznie trzeba żyć do końca swoich dni i gdzie trzeba tego życia dokonać. Jest to najlepsze miejsce na świecie, ale poza tym miejscem jest jeszcze wiele ładnych miejsc, które warte są tego, aby się nimi zainteresować i aby tam spędzić część swojego życia ${ }^{105}$.

Opowiadania Adama Zielińskiego przenoszą czytelnika w miniony świat galicyjski, na to owo legendarne pogranicze kilku kultur, gdzie gospodarzyli Ukraińcy, Polacy i Żydzi, każdy potrafił znaleźć dla siebie miejsce do życia. Są to pełne uroku teksty, nawiązujące do najlepszych stron Josepha Rotha, Manes Sperbera czy Józefa Wittlina, wielkich mistrzów wyczarowujących klimat, także duchowy, tamtych stron.

Właśnie w małych formach literackich, w opowiadaniach, leży najwyraźniej największa siła narracyjna Adama Zielińskiego. To tutaj jego literacki artyzm osiąga największe mistrzostwo. A warto przypomnieć, że najwięksi pisarze właśnie w małych formach upatrywali probierza rzeczywistych talentów.

To w opowiadaniach Adam Zieliński potrafi zastosować subtelny opis, celną charakterystykę, ciekawie poprowadzony dialog. Częstym jego zabiegiem konstrukcyjnym jest przenikanie się różnych planów czasowych, teraźniejszości z przeszłościa, nie tylko tą zapamiętaną ze słonecznej młodości, ale także z tą okresu grozy wojennej czy powojennych totalitaryzmów różnej maści.

A warto przypomnieć, że jednym z naczelnych posłań artystycznych, które stawia sobie Adam Zieliński jako pisarz, jest przeciwstawienie się wszelkiego rodzaju totalitaryzmowi. Jak sam powiada, "totalitaryzm zawsze w każdej swej formie zagraża podstawowym granicom wolności i bez wattpienia stanowi niebezpieczny regres w rozwoju społeczeństw. Niestety, nie należy on do zjawisk przeszłości, a więc do zaginionego świata (...). Wręcz odwrotnie! Dlatego moim skromnym piórem zwalczam każdy totalitaryzm, gdzie tylko mogę... ${ }^{106}$.

Dziennikarski temperament Adama Zielińskiego dał o sobie znać nie tylko w atrakcyjnych, jakkolwiek nierzadko trudnych i drażliwych tematach, ale także w sprawnej konstrukcji akcji.

Żywiołem, w którym Adam Zieliński czuje się wyraźnie „,na literackim luzie", jest wywiad-rzeka. Po dwóch książkach-wywiadach przeprowadzonych przez Tadeusza Kraśkę: Z Adamem Zielińskim wiedeńskie rozmowy (1995) oraz Gdzie jest niedźwiedź, czyli z Adamem Zielińskim wiedeńskich rozmów ciag dalszy (1998), ukazała się w 1999 r. kolejna, trzecia pozycja

${ }^{105}$ L. Żuliński, Jest źle, ale mogłoby być gorzej. Rozmowa z Adamem Zielińskim, Kraków-Rzeszów-Wiedeń 1999, s. 118.

106 Ibidem, s. 82. 
tego typu, tym razem przygotowana przez Leszka Żulińskiego pt. Jest źle, ale mogłoby być gorzej...

W tych wywiadach-rzekach dał się Adam Zieliński poznać jako rozmówca pełen swady, ale i głębokiej, filozoficznej zadumy. Wyraźnie tutaj widać linię jego zainteresowań, przekonań i doświadczeń życiowych. Na tę dzisiejszą pozycje Adama Zielińskiego w intelektualnym krajobrazie Wiednia i Polski składają się całe dziesięciolecia pracy, lektur, rozmów z partnerami pod różnymi szerokościami geograficznymi, setki dalekich, jak i bliższych podróży, zajmowanie się historia, polityką, historią kultury, literatura, ekonomią i tysiącem innych spraw, które powinien poznać współczesny biznesmen i intelektualista wysokiej, międzynarodowej klasy.

Refleksje Adama Zielińskiego nad rozlicznymi faktami otaczającymi naszą codzienną egzystencję, nad zagrożeniami niesionymi przez współczesną cywilizację, nad sprawami religii, sumienia, ojczyzny czy rodziny, a także nad wieloma innymi problemami współczesnego świata pozwalają podziwiać $\mathrm{w}$ jego osobie wierzącego w siebie, ale i mającego jasno sprecyzowany przed sobą cel człowieka. Jednoczy on w sobie nie tylko zdecydowanie, wiedzę i wytrwałość w dążeniu do wytkniętego sobie zadania, ale daje się także poznać jako jednostka subtelna, wrażliwa na piękno przyrody, dzieł sztuki...

Gdyby zebrać te wypowiedzi Adama Zielińskiego w jedną całość, powstałby z tego traktat, jak żyć w kończącym się stuleciu, pięknym, ale i brutalnym, zarówno dla jednostek, jak i całych narodów.

$\mathrm{W}$ zakończeniu pierwszego z wywiadów-rzek, w tomie $\mathrm{Z}$ Adamem Zielińskim wiedeńskie rozmowy, zawarty został jakby „alfabet Zielińskiego", rodzaj mini słownika ukazującego jego poglądy zredukowane tutaj do krótkich wypowiedzi. Wśród wielu bardzo cennych i dobrze przemyślanych zdań szczególne wrażenie robi hasło "O” - jak odpowiedzialność, w którym Adam Zieliński mówi m.in.: „To wielka sprawa. Czuję się odpowiedzialny za siebie, za moją rodzinę, za miasto w którym żyję, za państwo, którego jestem obywatelem. Czuję się odpowiedzialny nawet za ,mój' świat, za ziemię eksploatowaną nieludzko, żarłocznie, co zasługuje na największą karę! Szkoda mi ziemi! ,Mojej , przecież ziemi, czuję się za nią odpowiedzialny, jak za mój własny dom, i gdzie mogę, na miarę możliwości jednego człowieka, staram się broni jej piękna, jej wspaniałości..."107.

Oprócz własnej działalności literackiej, wiele uwagi poświęcał Adam Zieliński szeroko rozumianej działalności kulturalnej. Jako członek austriackiego PEN-Clubu rozwijał bardzo owocne inicjatywy, znajdujące szeroki rezonans nie tylko w Wiedniu.

107 T. Kraśko, Z Adamem Zielińskim wiedeńskie rozmowy, op. cit., s. 117-118. 
Także w Polsce wiele uwagi poświęcał środowiskom literackim i kulturalnym, m.in. Salonowi Literackiemu Jana Poprawy w Krakowie czy miesięcznikowi „Ziemia Bocheńska”.

Dał się też poznać Adam Zieliński - wraz z małżonką Zofią - jako fundator cennych poloników literackich, jak m.in. w postaci ofiarowania przez dr Zofię Zielińską nieznanego listu Henryka Sienkiewicza z 1895 r. do jego austriackiej tłumaczki w sprawie przekładu na niemiecki powieści Quo vadis? Cenny autograf znalazł schronienie w poznańskim Muzeum Literackim im. Henryka Sienkiewicza, uzyskany przez tę placówkę jesienią $1997 \mathrm{r}$.

Ostatnie lata życia wiedeńskiego pisarza to w dalszym ciągu wytężona praca literacka. Publikuje kolejne utwory, m.in. głośną nad Dunajem powieść Wien. Ein Fall (2002) ${ }^{108}$ następnie kolejną powieść An der Weichsel $(2006)^{109}$.

Rok 2007 przynosi bardzo interesującą książkę wspomnieniową Höre nie auf zu lernen, w której Adam Zieliński opowiada o swojej przeszłości, ale i o swoich licznych podróżach po świecie, o spotkanych ciekawych ludziach ${ }^{110}$.

Ostatnią książką są Opowiadania z roku 2008. Warto dodać, iż od roku 2000 rozpoczęły się ukazywać (pod red. Tadeusza Skoczka i Leszka Żulińskiego) jego Utwory wybrane. Adam Zieliński zmarł po dłuższej chorobie 26 czerwca 2010 roku w Wiedniu.

\section{Zusammenfassung}

\section{LITERARISCHE POLONOPHILE}

Österreichisch - polnische Literaturbeziehungen, ähnlich wie auch die im Bereich der Politik, sind seit Jahren von bester Qualität. Der Aufsatz berichtet über drei besonders verdiente Schriftsteller und Übersetzer: Oskar Jan Tauschinski, Gerda Leber-Hagenau und Adam Zielinski, die mehrere Titel von literarischen Werken ins Polnische übersetzt oder auch zahlreiche Bücher über Polen verfasst haben. Aus ihrer Feder stammen auch poetische oder belletristische Werke, die sowohl in Österreich, als auch in Polen bekannt sind. Ihre langjährigen Aktivitäten trugen wesentlich zur Popularität der polnischen Kultur, vor allem der Literatur, bei.

108 W Polsce ukazała się pt. Wiedeńczycy, Wrocław 2003.

109 W Krakowie ukazała się rok wcześniej pt. Nad Wisła (2005) oraz w Bochni 2006 roku

110 W Polsce tom ten ukazał się pt. Fotoplastykon. Stryj, Lwów, Kraków, Wiedeń i niemal cały świat, Wrocław 2009. 